\title{
INTEGRATED TERMINAL IN SEMARANG WITH A MODERN ARCHITECTURAL APPROACH TERMINAL TERPADU DI SEMARANG DENGAN PENDEKATAN ARSITEKTUR MODERN
}

\author{
Saeful Anam ${ }^{1)}$, Gatoet Wardianto ${ }^{2)}$, Anityas Susanti ${ }^{3)}$ \\ Program Studi Arsitektur, Fakultas Teknik, Universitas Pandanaran \\ Jl. Banjarsari Barat No.1, Pedalangan, Banyumanik, Semarang \\ saefulanam@unpand.ac.id ${ }^{1)}$ \\ gatoetwarianto@yahoo.com ${ }^{2)}$ \\ anityass@yahoo.com ${ }^{3)}$
}

\begin{abstract}
Abstrak
Terminal adalah sustu tempat dimana transportasi umum mengawali ataupun mengakhiri dalam pelayanan masyarakat yang sedang melakukan perjalanan.Terminal sangatlah penting dalam menyelenggarakan angkutan umum saat ini. Karena terminal yaitu tempat untuk pertemuan antara penyedia jasa maupun pengguna jasa itu sendiri, tempat dimana membawa penumpang ataupun barang, tempat dimana pada saat melakukan perjalanan ataupun mengakhiri perjalanan kendaraan umum, mengawasi, mengatur serta mengoprasikan lalulintas, dan tempat peristirahatan bagi angkutan umum. Kajian pola sirkulasi pada terminal ini menunjukkan adanya permasalahan parker ataupun arus kendaraan pada terminal yang masih perlu di tingkatkan lagi. Tempat parkir dan sirkulasi kendaraan pada terminal yang harus ditingkatkan lagi, Sirkulasi pada terminal sangat berpengaruh besar terhadap kelancaran dan mencegah crossing antar transportasi dengan pengguna pada terminal.
\end{abstract}

Kata kunci: Terminal bus,transportasi umum, sirkulasi terminal, lalulintas

\begin{abstract}
Terminal is a place where public transportation starts or ends in the service of people who are traveling. Terminal is very important in organizing public transportation today. Because the terminal is a place for meetings between service providers and service users themselves, a place where carrying passengers or goods, a place where when traveling or ending public transportation trips, supervising, managing and operating traffic, and a resting place for public transportation. The study of circulation patterns in this terminal shows the problem of parking or vehicle flow in the terminal which still needs to be improved again. Parking lots and vehicle circulation at the terminal must be increased again. Circulation at the terminal has a great influence on the smoothness and prevents crossing between transportation with users at the terminal.
\end{abstract}

Keywords: Bus terminal, public transportation, terminal circulation, traffic

\section{PENDAhUluAN}

\section{Latar Belakang}

Terminal sebagai pengawasan dan pengendalian dari jaringan lalu lintas, dan merupakan perasarana transportasi yang digunakan untuk sistem transportasi serta merupakan unsur tata ruang yang memiliki peran penting bagi efisien dalam truktur wilayah.

\section{Tujuan}

Mendapatkan landasan konseptual $\mathrm{p}$ erencanaan dan perancangan sebuah bangunan terminal bus terpadu di kota semarang yang merupakan tempat pusatnya daerah jawa tengah dan kota semarang merupakan titik tengah jalan pantura dari Jakarta menuju Surakarta.

\section{Manfaat}


a) Untuk Pemerintah Kota Semarang

- Untuk memberi masukan kepada pemerintah kota semarang dari segi konsep dan desain terminal tersebut.

b) Untuk Masyarakat Kota Semarang

- Menjadikan terminal yang aman nyaman dan menyajikan fasilitas yang baik untuk masyarakat kota semarang maupun luar kota.

\section{Batasan}

Dalam penulisan laporan ini, bertujuan untuk mendesain sebuah terminal terpadusebagai pusat transportasi di semarang. Dalam sistem perkotaan nasional,kedudukan kota semarang merupakan kota yang berfungsi sebagai pusat kegiatan nasional, dan terletak diantara dua kutub pertumbuhan perekonomian, yaitu Jakarta yang berada disebelah barat dan Surabaya di timur. Kedua kutub ini memiliki tingkat pertumbuhan yang lebih tinggi disbanding dengan semarang. Oleh karena itu, perlu adanya strategi guna menarik pertumbuhan ke semarang, minimal menampung arus gerak regional Jawa Tengah. Penetapan sebagai pusat kegiatan nasional ini karena kota semarang berpotensi sebagai:

a) Pusat pengembangan transportasi yang mempunyai potensi sebagai pintu gerbang ke kawasan nasional dan mempunyai potensiuntuk mendorong daerah yang disekitarnya.

b) Pusat jasa pemerintahan untuk nasional atau meliputi beberapa propinsi.

c) Pusat jasa-jasa pelayanan keuangan / perbankan yang melayani secara nasional atau beberapa propinsi.

d) Pusat pengolahan/pengumpul barang secara nasional atau propinsi.

\section{TINJAUAN TEORI}

\section{Pengertian Terminal Bus}

Terminal bus adalah perasarana untuk angkutan jalan raya guna untuk mengatur kedatangan pemberangkatan pangkalannya kendaraan umum serta memuat atau menurunkan penumpang atau barang.

\section{Fungsi Terminal Bus}

Dari beberapa ahli Edward' $\mathrm{K}$ Morlok, 2005 dan Suwardjoko P, Warpani, 2002 dapat disimpulkan bahwa terminal bus mempunyai fungsi sebagai:

a) Terminal bagi penumpang adalah untuk kenyamanan menunggu, kenyamanan perpindahan dari satu moda atau kendaraan lain, tempat fasilitas-fasilitas informasi dan fasilitas kendaraan peribadi.

b) Terminal bagi pemerintah adalah segi perencanaan dan manajemen lalu lintas untuk menata lalu lintas dan angkutan serta menghindari dari kemacetan.

c) Terminal bagi operator adalah untuk mengatur operasi bus, penyediaan fasilitas istirahat dan informasi bagi awak bus dan sebagai fasilitas istirahat dan informasi bagi awak bus dan sebagai fasilitas pangkalan.

d) Terminal bagi pengguna umum adalah untuk fasilitas yang mendukung dalam suatu terminal antara lain mushola, toilet, tiket, pembelanjaan, dll.

Jenis Terminal Bus (Warpani, 2002)

Berdasarkan jenis angkuta terminal bus dibedakan menjadi :

a) Terminal Penumpang, adalah prasarana transportasi jalan untuk keperluan menaikkan dan menurunkan penumpang, perpindahan intra antara moda transortasi serta pengaturan kedatangan dan pembarangkatan kendaraan umum. 
b) Terminal barang, adalah prasarana transportasi jalan untuk keperluan membongkar dan memuat barang dan perpindahan intra dan antar moda transportasi.

Klasifikasi Terminal Bus (Warpani, 2002)

A. Berdasarkan peranannya dibagi menjadi:

a) Terminal Primer, untuk pelayanan arus barang dan penumpang (jasa angkutan) yang terjangkau regional (antar kota, provinsi atau antar negara).

b) Terminal Sekunder, untuk pelayanan arus penumpang (jasa angkutan yang bersifat local dan atau melengkapi kegiatan terminal perimer dalam kota).

B. Berdasarkan muatan adalah :

a) Fasilitas utama yang tersedia adalah ruang untuk penumpang dan ruang area kendaraan.

b) Kendaraan yang terlibat biasanya bus antar kota, bus antar propinsi, bus kota, angkuta umum, taksi, dll.

C. Menurut trayek jangkauan operasional moda angkutan :

a) Terminal angkutan kota adalah merupakan titik temu dan titik sebar perjalanan dalam kota.

b) Terminal angkutan antar kota adalah merupakan titik temu dan titik sebar perjalanan antar kota yang satu dengan yang lain.

c) Terminal gabungan adalah merupakan terminal yang melayani perpindahan perjalanan dalam kota ke perjalanan antar kota dan sebaliknya.

D. Indicator Terminal Penumpang

a) Keamanan Kriteria ini akan menilai sistem keamanan dari fasilitas transportasi di suatu terminal penumpang dan meningkatkan pelayanan transportasi penumpang.

b) Pemeliharaan Kriteria ini akan menilai pemeliharaan pihak terkait dalam mempertahankan infrastruktur dalam pelayanan di tempat penampung. c) Manajemen Kriteria ini akan menilai bagaimana manajemen operasional terminal penumpang dapat mendorong manajemen yang lebih baik, sehingga sistem operasional terminal penumpang dapat lebih baik.

d) Aksebilitas Kriteria ini menilai bagaimana suatu terminal penumpang dapat meningkatkan akses pelayanan bagi penumpang.

e) Sistem keterhubungan Kriteria ini akan menilai bagaimana terminal penumpang memiliki keterhubungan terminal penumpang lainnya.

f) Realibility Kriteria ini menilai bagaimana pemaduan transportasi terminal penumpang dapat meningkatkan waktu tempuh perjalanan, Fungsi terminal penumpang menurut Morlok, 2005 adalah :

1. Menurut penumpang ke atas kendaraan transportasi dan menurunkannya.

2. Memindahkan dari suatu kendaraan ke kendaraan lainnya.

3. Menampung penumpang dari waktu tiba dan sampai waktu berangkat, seperti menyediakan kenyamanan penumpang.

4. Menyimpan kendaraan dan komponen lainnya, memelihara dan menentukan tugas selanjutnya.

5. Mengumpulkan penumpang di dalam ukuran ekonomis untuk dapat di angkut dan menurunkannya sesudah tiba di tempat tujuan.

\section{Pengertian Arsitektur Modern}

Arsitektur modern adalah suatu bangunan dengan gaya karakteristik serupa yang mengutamakan kesederhanaan bentuk dan menghapus segala macam ornamen. Menurut Rayner Banham pada bukunya yang berjudul "Age of the Master : A Personal view of Modern Architecture", tahun 1978, perkembangan arsitektur 
modern menekankan pada kesederhanaan suatu desain dengan menganut Form Follows Function (bentuk mengikuti fungsi) Arsitektur modern timbul karena adanya kemajuan dalam bidang eknologi yang membuat manusia cenderung untuk sesuatu yang ekonomis. Arsitektur modern pertama kali muncul pada tahun 1900, pada tahun 1940 gaya ini telah diperkuat dan dikenal dengan gaya Internasional dan menjadi bangunan yang dominan dalam abad ke-20.

Arsitektur modern timbul karena adanya kemajuan dalam bidang teknologi yang membuat manusia cenderung lebih memilih sesuatu yang praktis dan ekonomis. Arsitektur Modern memiliki prinsip yaitu fungsional dan efisiensi, Fungsional yang artinya bangunan tersebut harus mewadahi aktifitas penghuninya dan efisiensi harus mampu diterapkan keberbagai hal seperti efisiensi biaya, efiiensi waktu pengerjaan dan aspek fee maintenance pada bangunan.

\section{Ciri-Ciri Arsitektur Modern}

a) Ornamen adalah suatu kejahatan sehingga perlu ditindakan. Penambahan ornament dianggap suatu hal yang tidak efisien karena dapat dianggap tidak memiliki fungsi.

b) Bentuk arsitektur yang memiliki fungsi.

c) Nihilism, penekanan perancangan pada space, maka desain menjadi polos, sederhana dan bidang-bidang kaca lebar.

d) Kejujuran bahan jenis bahan atau material yang digunakan diekspos secara polos, ditampilkan apa adanya dan tidak ditutup-tutupi sedemikian rupa hingga karakter aslinya

\section{METODOLOGI}

\section{Pendekatan Aspek Fungsional Pelaku Aktifitas}

Jenis pelaku aktifitas pada terminal bus dibedakan menjadi 2, yaitu:

A. Pengunjung

$$
\begin{array}{cccc}
\text { Pengunjung } & \text { terminal adalah orang } \\
\text { yang sengaja } & \text { berkunjung } & \text { untuk }
\end{array}
$$

melakukan kegiatan yang berkaitan aktifitas transportasi darat dengan cara menggunakan berbagai fasilitas didalam terminal bus. Pengunjung dalam terminal bus terdiri dari 3 jenis aktivitas :

a) Penumpang adalah orang yang sengaja berkunjung ke terminal bus untuk menggunakan moda transportasi darat dalam rangka melakukan perjalanan menuju suatu tempat.

b) Mengantar / menjemput adalah orang yang hanya mengantar / menjembut orang yang ingin menggunakan bus.

c) Pengunjung khusus adalah orang berkunjung ke terminal untuk melakukan kegiatan khusus seperti, studi tour, pembangunan, penelitian dll.

B. Pengelola

Pengelola terminal bus adalah orang yang bertanggung jwab tarhadap aktifitas yang terjadi pada terminal bus. Pengelolla dalam terminal bus juga dibedakan menjadi 2 jenis aktifitas, yaitu :

a) Pengelolla transportasi dan operasional utama adalah orang yang bertanggung jawab terhadap kegiatan administrasi dan kegiatan operasional pada terminal bus.

b) Pengelola Operasional Servis adalah orang yang bertanggung jawab terhadap kegiatan pendukung aktifitas utama dan juga kegiatan servis, seperti petugas keamanan lingkungan terminal bus, petugas mekanikal, peugas cleaning service. 
Aktifitas dan Kebutuhan Ruang

\section{a. Petugas Terminal}

Tabel 1. Aktifitas \& Kebutuhan Ruang Petugas Terminal

\begin{tabular}{|c|c|c|c|c|}
\hline No & Penggum & $\begin{array}{l}\text { Keterangan } \\
\text { Pengguna }\end{array}$ & Aktifitas & Kebutuban Ruang̨ \\
\hline 1 & $\begin{array}{l}\text { Kepala } \\
\text { Terminal }\end{array}$ & $\begin{array}{l}\text { Mengontrol Semas } \\
\text { Kegiatan Terminal }\end{array}$ & $\begin{array}{l}\text { - Datang } \\
\text { - Memarkir Kendarasa } \\
\text { - Menuju Kantor } \\
\text { - Rapait } \\
\text { - Berkeliting Terrninal } \\
\text { - Ishoma } \\
\text { - Pulang }\end{array}$ & $\begin{array}{l}\text { - T. Partir } \\
\text { Pengebla } \\
\text { - Kantor Kepala } \\
\text { Termital } \\
\text { - R. Rapat } \\
\text { - Food court } \\
\text { - Dapur } \\
\text { - Musholla }\end{array}$ \\
\hline 2 & $\begin{array}{c}\text { Kepala } \\
\text { Seksi } \\
\text { Kebersihat, } \\
\text { Ketertiban, } \\
\text { dan } \\
\text { Keamanan }\end{array}$ & $\begin{array}{l}\text { Mengentrol Semai } \\
\text { Kegiatun Kebersittan, } \\
\text { Ketertban, dan } \\
\text { Keamanan }\end{array}$ & $\begin{array}{l}\text { - Datang } \\
\text { - Memarkit Kendaraia } \\
\text { - Menuju Kantor } \\
\text { - Rapat } \\
\text { - Berkeliling Terminal } \\
\text { - Ishoma } \\
\text { - Pulang }\end{array}$ & $\begin{array}{l}\text { - T. Partiir } \\
\text { Pengeblata } \\
\text { - Kantot Kepala Sdsi } \\
\text { - R. Rapat } \\
\text { - Food court } \\
\text { - Dapur } \\
\text { - Mushella } \\
\text { - Menan pengawas }\end{array}$ \\
\hline 3 & $\begin{array}{c}\text { Kepala } \\
\text { Seksi } \\
\text { Pengaturas }\end{array}$ & $\begin{array}{l}\text { Mengentrol Sema } \\
\text { Kegiatun Operasional }\end{array}$ & $\begin{array}{l}\text { - Datang } \\
\text { - Memarkit Kendaraan }\end{array}$ & $\begin{array}{l}\text { - T. Parlit } \\
\text { Pergeblala } \\
\text { - Kantor Kepala } \\
\text { - Menana pengaws }\end{array}$ \\
\hline & Operasional & & $\begin{array}{l}\text { - Menuju Kantor } \\
\text { - Rapat } \\
\text { - Berkeliling Terminal } \\
\text { - Isboma } \\
\text { - Pulang }\end{array}$ & $\begin{array}{l}\text { Selsi } \\
\text { - R. Ragat } \\
\text { - Food court } \\
\text { - Dapur } \\
\text { - Musholla } \\
\text { - Menan pengawas } \\
\end{array}$ \\
\hline 4 & \begin{tabular}{|c|} 
Pecugas \\
Kebersilan
\end{tabular} & $\begin{array}{l}\text { Bertanggung jawb } \\
\text { membersihkan } \\
\text { lingkungan terminal }\end{array}$ & $\begin{array}{l}\text { - Datang } \\
\text { - Memarkit Kendaran } \\
\text { - Menuju Ksntor } \\
\text { - Menuju R. Peralatan } \\
\text { Kebersihan } \\
\text { - Membersihkan Terninal } \\
\text { - Ishoma } \\
\text { - Pulang }\end{array}$ & $\begin{array}{l}\text { - T. Partir } \\
\text { Pengebla } \\
\text { - Kantor Petugos } \\
\text { Keberihas } \\
\text { - R. Peralatan } \\
\text { Kebersihan } \\
\text { - Food court } \\
\text { - Dapur } \\
\text { - Musholla } \\
\text { - Menana pengawas }\end{array}$ \\
\hline 5 & $\begin{array}{l}\text { Petugas } \\
\text { Keamanan }\end{array}$ & $\begin{array}{l}\text { Bentanggung jawab } \\
\text { mengontrol kcamananan } \\
\text { terminal }\end{array}$ & $\begin{array}{l}\text { - Datang } \\
\text { - Memarkir Kendaraan } \\
\text { - Menuju Kantor } \\
\text { - Mengontol keamanan } \\
\text { terminal nelalui monitor } \\
\text { - Patroli } \\
\text { - lchoma } \\
\text { - Pulang }\end{array}$ & $\begin{array}{l}\text { - T. Parkir } \\
\text { Pengelola } \\
\text { - Kuntor Pctuyas } \\
\text { Keamanan } \\
\text { - Food court } \\
\text { - Dupur } \\
\text { - Muchalla }\end{array}$ \\
\hline 6 & $\begin{array}{c}\text { Petugass } \\
\text { Mekanikal } \\
\text { Elckatrikal }\end{array}$ & $\begin{array}{l}\text { Bertanggung jawab } \\
\text { mengontrol sistem } \\
\text { uilitiss terminal }\end{array}$ & 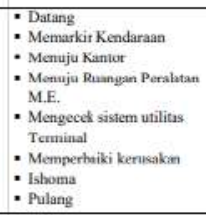 & $\begin{array}{l}\text { - T.Purkir } \\
\text { Penglola } \\
\text { - Kantor Petuges M.E. } \\
\text { - R Peralatan ME. } \\
\text { - Foad court } \\
\text { - Dapur } \\
\text { - Musholla } \\
\text { - Menara pengaxas }\end{array}$ \\
\hline 7 & $\begin{array}{c}\text { Petugas } \\
\text { Administrax } \\
i\end{array}$ & $\begin{array}{l}\text { Bertugas Menangani } \\
\text { Administraki Terminal }\end{array}$ & $\begin{array}{l}\text { - Datang } \\
\text { : Mermarkir Kendaraan } \\
\text { - Menuju Kantor }\end{array}$ & \begin{tabular}{|l|} 
- T. Parkit \\
Pengelola \\
- Kantor Petugas \\
Administrasi \\
\end{tabular} \\
\hline & & & \begin{tabular}{|l|l|} 
- Bckerja \\
: Isboma \\
- Pulang \\
\end{tabular} & $\begin{array}{l}\text { - Food court } \\
\text { - Dapur } \\
\text { - Musholla } \\
\end{array}$ \\
\hline 8 & $\begin{array}{c}\text { Petugas } \\
\text { Ifformasi }\end{array}$ & $\begin{array}{l}\text { Berrugas Meraberi } \\
\text { laformasi Kepats } \\
\text { Pengunjung }\end{array}$ & 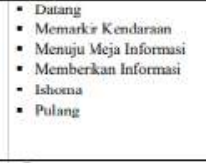 & 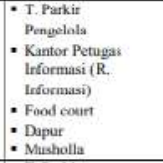 \\
\hline 9 & $\begin{array}{l}\text { Potuguan } \\
\text { Tiket }\end{array}$ & $\begin{array}{l}\text { Melayani Penjualen } \\
\text { Tiket Peron }\end{array}$ & $\begin{array}{l}\text { - Datang } \\
\text { - Memarkir Kendaraan } \\
\text { - Menuju Leket } \\
\text { - Melayani Penjualan Tiket } \\
\text { - Ishoma } \\
\text { - Pulang }\end{array}$ & $\begin{array}{l}\text { - T. Parkir } \\
\text { Pengelola } \\
\text { - Kantor Petugas Tiket } \\
\text { (Loket) } \\
\text { - Faod eosint } \\
\text { - Dapur } \\
\text { - Nusholla } \\
\end{array}$ \\
\hline 10 & $\begin{array}{c}\text { Semua } \\
\text { Pengelola }\end{array}$ & Faeilitain Untuk Pongeloha & - Metabolisime & $\begin{array}{l}\text { - Toliet Pria } \\
- \text { - Totlet Wanita }\end{array}$ \\
\hline
\end{tabular}

\section{b. Aktifitas dan Kebutuhan Ruang Pengelola}

Tabel 2. Aktifitas \& Kebutuhan Ruang Pengelola Retail/Kios

\begin{tabular}{|c|c|c|c|c|}
\hline No & Pengguna & $\begin{array}{c}\text { Keterangan } \\
\text { Pengguna }\end{array}$ & Aktifitas & Kebutuhan Ruang \\
\hline 1 & Food Court & $\begin{array}{l}\text { Warung, Kaffe, } \\
\text { Restoran }\end{array}$ & $\begin{array}{l}\text { - Datang } \\
\text { - Memarkir } \\
\text { Kendaraan } \\
\text { - Menuju Food } \\
\text { Cour } \\
\text { - Mclayani } \\
\text { Pelanggan } \\
\text { - Isboma } \\
\text { - Pulang } \\
\end{array}$ & $\begin{array}{l}\text { - T. Parkir } \\
\text { Pengelola } \\
\text { - Food Court } \\
\text { - Dapur } \\
\text { - Mushola }\end{array}$ \\
\hline 2 & Shnenir & $\begin{array}{l}\text { Menjual Cinderamata } \\
\text { Khas Blitar }\end{array}$ & $\begin{array}{l}\text { - Datang } \\
\text { - Memarkir } \\
\text { Kendaraan }\end{array}$ & $\begin{array}{l}\text { - T. Parkir } \\
\text { Pengelola } \\
\text { - Kios Souvenir }\end{array}$ \\
\hline & & & $\begin{array}{l}\text { - Menuju Kios } \\
\text { - Melayani } \\
\text { Pelanggan } \\
\text { - Isboma } \\
\text { - Pulang }\end{array}$ & $\begin{array}{l}\text { - Food Court } \\
\text { - Mushola }\end{array}$ \\
\hline 3 & $\begin{array}{l}\text { Korum dan } \\
\text { Majalah }\end{array}$ & $\begin{array}{l}\text { Menjual Koran, } \\
\text { Majalah, dan Buku } \\
\text { Cetak Lainnya }\end{array}$ & $\begin{array}{l}\text { - Datang } \\
\text { - Memarkir } \\
\text { Kendaraan } \\
\text { - Menuju Kios } \\
\text { - Melayani } \\
\text { Pelanggan } \\
\text { - Shooma } \\
\text { - Pulang } \\
\end{array}$ & $\begin{array}{l}\text { - T. Parkir } \\
\text { Pengelola } \\
\text { - Kios Majalah } \\
\text { - Food Court } \\
\text { - Mushola }\end{array}$ \\
\hline 4 & $\begin{array}{l}\text { Wanung } \\
\text { Telekom } \\
\text { dan } \\
\text { Counter } \\
\text { Pirisa }\end{array}$ & $\begin{array}{l}\text { Melayani Sewa Telepon } \\
\text { Umum dan menjual } \\
\text { pulsa telepon gengagam }\end{array}$ & $\begin{array}{l}\text { - Datang } \\
\text { - Memarkir } \\
\text { Kendaraan } \\
\text { - Menuju Kios } \\
\text { - Melayani } \\
\text { Pelanggan } \\
\text { - Isborna } \\
\text { - Pulang } \\
\end{array}$ & $\begin{array}{l}\text { - T. Parkir } \\
\text { Pengelola } \\
\text { - Kios Wartel \& } \\
\text { Counter } \\
\text { - Food Court } \\
\text { - Mushola }\end{array}$ \\
\hline 5 & 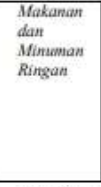 & & \begin{tabular}{|l} 
- Datang \\
- Memarkir \\
Kendaraan \\
- Menuju Kios \\
- Melayani \\
Pelanggan \\
- Istoma \\
- Pulang \\
\end{tabular} & $\begin{array}{l}\text { - T. Parkir } \\
\text { Pengelola } \\
\text { - Kios Makanan \& } \\
\text { Minuman Ringant } \\
\text { - Food Court } \\
\text { - Mushoda }\end{array}$ \\
\hline 6 & $\begin{array}{l}\text { Penukaran } \\
\text { Uang }\end{array}$ & & $\begin{array}{l}\text { - Datang } \\
\text { - Memarkir } \\
\text { Kendaraan } \\
\text { - Menuju Kios } \\
\text { - Melayani } \\
\text { Pelanggan } \\
\text { - Ishoma } \\
\text { - Pulang } \\
\end{array}$ & $\begin{array}{l}\text { - T. Parkir } \\
\text { Pengelola } \\
\text { - Kios Penukaran } \\
\text { Uang } \\
\text { - Food Court } \\
\text { - Musholata }\end{array}$ \\
\hline 7 & $\begin{array}{l}\text { Agen } \\
\text { Perjalanan }\end{array}$ & & $\begin{array}{l}\text { - Datang } \\
\text { - Memarkir } \\
\text { Kendaraan } \\
\text { - Menuju Kios } \\
\text { - Melayani } \\
\text { - Pelanggan } \\
\text { - Ishoma } \\
\text { - Pulang } \\
\end{array}$ & $\begin{array}{l}\text { - T. Parkir } \\
\text { Peagelola } \\
\text { - Kios Agen } \\
\text { Perjalanan } \\
\text { - Food Court } \\
\text { - Mushola }\end{array}$ \\
\hline 8 & $\begin{array}{c}\text { Semua } \\
\text { Pengelola } \\
\text { Kios } \\
\end{array}$ & $\begin{array}{l}\text { Fasilitas Untuk Semwa } \\
\text { Pengelola Kios }\end{array}$ & $\begin{array}{l}\text { - Metabolisme } \\
\text { - Membersihkan Diri }\end{array}$ & $\begin{array}{l}\text { - Toilet Pria } \\
\text { - Toilet Wanita }\end{array}$ \\
\hline
\end{tabular}




\section{c. Aktifitas dan Kebutuhan Ruang Pengunjung}

Tabel 3. Aktifitas \& Kebutuhan Ruang Pengunjung

\begin{tabular}{|c|c|c|c|c|}
\hline No. & Pengguna & $\begin{array}{l}\text { Keterangan } \\
\text { Pengsuma }\end{array}$ & Aktifitas & Kebutulan Ruang \\
\hline 1 & Penumpang & $\begin{array}{l}\text { Mencakup } \\
\text { penumpary yang } \\
\text { datang dan calon } \\
\text { penumparg, baik } \\
\text { Pejalan Kaki maupun } \\
\text { Menggunakan } \\
\text { Kendaraas Pribadi }\end{array}$ & $\begin{array}{l}\text { - Datang } \\
\text { - Memarkir Kendaraan } \\
\text { - Membeli Taket Peron } \\
\text { - Stolat } \\
\text { - Makan, Minum } \\
\text { - Belanja } \\
\text { - Melihat Informasj } \\
\text { - Menunggu } \\
\text { Bus Angkutan } \\
\text { - Berangkat }\end{array}$ & $\begin{array}{l}\text { - Tempat Parkir Uuium } \\
\text { - Loket } \\
\text { - Musholla } \\
\text { - Food Caurt } \\
\text { - Kios-kis } \\
\text { - R. Infornasi } \\
\text { - R. Tungza } \\
\text { - Proon Keberangkata n } \\
\text { - Peron } \\
\text { Kedatangan }\end{array}$ \\
\hline 2 & Pengagntar & $\begin{array}{l}\text { Pengantar } \\
\text { Menggunakan } \\
\text { Kendaraat Pribadi }\end{array}$ & $\begin{array}{l}\text { - Datang } \\
\text { - Memarkir Kendaraan } \\
\text { - Membeli Tiket Peron } \\
\text { - Makan, Minum } \\
\text { - Belanja } \\
\text { - Melihat Informasi } \\
\text { - Menunggu } \\
\text { - Pulang }\end{array}$ & $\begin{array}{l}\text { - Tempat Parkir Umam } \\
\text { - Loket } \\
\text { - Food Court } \\
\text { - Ktos-kios } \\
\text { - R. Infornasi } \\
\text { - R. Tungza } \\
\text { - Peron Keberangkata n } \\
\text { - Peron } \\
\text { Kedatangan }\end{array}$ \\
\hline \multirow[t]{2}{*}{3} & Penjenput & $\begin{array}{l}\text { Penjemput } \\
\text { Menggunakan } \\
\text { Kendaran Pritadi }\end{array}$ & $\begin{array}{l}\text { - Datang } \\
\text { - Memarkir Kendaraan } \\
\text { - Menunggu } \\
\text { - Makan, Minum } \\
\text { - Belanja }\end{array}$ & $\begin{array}{l}\text { - Tempat Parkir Umum } \\
\text { - Loket } \\
\text { - Food Caurt } \\
\text { - Kios-kics }\end{array}$ \\
\hline & & & $\begin{array}{l}\text { - Melihat Informasi } \\
\text { - Mununggu } \\
\text { - Pulang }\end{array}$ & $\begin{array}{l}\text { - R. Infornasi } \\
\text { - R. Tungza } \\
\text { - Peron Kcberangkata n } \\
\text { - Peron } \\
\text { Kedatangai }\end{array}$ \\
\hline 4 & \begin{tabular}{|l|} 
Semua \\
Pengygan \\
Terminal \\
\end{tabular} & \begin{tabular}{|l|} 
Fasilitas Lntuk \\
SemuaPengguna \\
Terminal
\end{tabular} & $\begin{array}{l}\text { - Metalolisme } \\
\text { - Mermbersihkan Diri }\end{array}$ & \begin{tabular}{|l|} 
- Toilet Pria \\
- Toiler Wanita
\end{tabular} \\
\hline
\end{tabular}

\section{d. Aktifitas dan Kebutuhan Ruang Armada} Bus

Tabel 4. Aktifitas \& Kebutuhan Ruang Armada Bus

\begin{tabular}{|c|c|c|c|c|}
\hline No. & Pengzanz & $\begin{array}{c}\text { Keterangan } \\
\text { Peugguaaa }\end{array}$ & Akcifitas & $\begin{array}{l}\text { Kebuthhas } \\
\text { Ruaag }\end{array}$ \\
\hline 1 & Armada Bus & $\begin{array}{l}\text { Mencakup Armata } \\
\text { Bus Antur Kota }\end{array}$ & 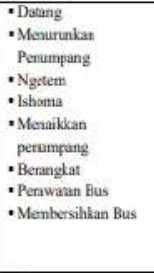 & 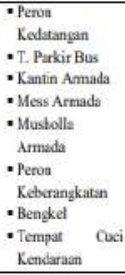 \\
\hline 2 & $\begin{array}{l}\text { Arnads } \\
\text { Angktuna } \\
\text { Unumm }\end{array}$ & $\begin{array}{r}\text { Menceakup Angkinan } \\
\text { Kona, } \\
\text { Anghuta antar Kota, } \\
\text { dan Anglutan Desa }\end{array}$ & 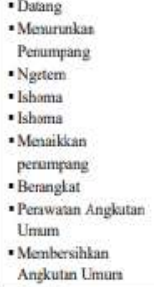 & 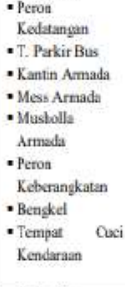 \\
\hline 3 & $\begin{array}{l}\text { Kebutuhan } \\
\text { bessama }\end{array}$ & $\begin{array}{l}\text { Fasisitas Untuk } \\
\text { Sernua Armada }\end{array}$ & $\begin{array}{l}\text { - Mcrabolisme } \\
\text { - Monbersihlan Diri } \\
\text { - Shelat } \\
\text { - Mskan } \\
\text { - Istirahat }\end{array}$ & $\begin{array}{l}\text { : Toilct Pra } \\
: \text { Toild } \\
: \text { Mustola } \\
: \text { : Mantin } \\
\end{array}$ \\
\hline
\end{tabular}

\section{Program Besaran Ruang}

a. Fasilitas Pelayanan Penumpang

Tabel 5. Program Besaran Ruang Fasilitas Pelayanan Penumpang

\begin{tabular}{|c|c|c|c|c|c|c|}
\hline No & Ruang & $\begin{array}{l}\text { Kebutuhan } \\
\text { Perabot }\end{array}$ & $\begin{array}{l}\text { Pendekatan } \\
\text { / orang }\end{array}$ & Kapasitas & $\begin{array}{c}\text { Luas } \\
\text { Ruang }\end{array}$ & Sumber \\
\hline 1 & \begin{tabular}{|l|} 
Pusat \\
Informasi
\end{tabular} & $\begin{array}{l}\text { Meja, kursi, } \\
\text { komputer }\end{array}$ & $2 \mathrm{~m}^{2}$ & $\begin{array}{l}20 \text { Orang }+ \\
\text { sitkulasi } \\
50 \%\end{array}$ & $60 \mathrm{~m}^{2}$ & An \\
\hline 2 & \begin{tabular}{|l} 
Ruang \\
Tunggu \\
penumpang
\end{tabular} & $\begin{array}{l}\text { CCTV, Fasilitas } \\
\text { duduk dan fasilitas } \\
\text { hiburan ( telivisi) }\end{array}$ & $0,8 \mathrm{~m}^{2}$ & $\begin{array}{l}600 \text { Orang + } \\
\text { sirkulasi } 50 \%\end{array}$ & $720 \mathrm{~m}^{2}$ & NDA \\
\hline 3 & \begin{tabular}{|l|} 
Smooking \\
Area Room \\
\end{tabular} & $\begin{array}{l}\text { CCTV, Kursi, } \\
\text { meja, astsak, } \\
\text { exhaust fan }\end{array}$ & $0,8 \mathrm{~m}^{2}$ & $\begin{array}{l}100 \text { Orang }+ \\
\text { Sitkulasi } \\
50 \%\end{array}$ & $120 \mathrm{~m}^{2}$ & $\mathrm{NDA}$ \\
\hline 4 & $\begin{array}{l}\text { Retail-retail } \\
\text {-ATM } \\
\text { Center } \\
\text { - Money } \\
\text { Changer } \\
\text { - frod court }\end{array}$ & $\begin{array}{l}\text { Tergantung } \\
\text { pengguna fungsi } \\
\text { retail }\end{array}$ & $\begin{array}{l}\cdot 1,2 \mathrm{~m}^{2} \\
\cdot 0,8 \mathrm{~m}^{2} \\
\cdot 0,8 \mathrm{~m}^{2}\end{array}$ & $\begin{array}{l}-20 \text { box } \\
\\
-20 \text { Orang }+ \\
\text { Sirkulasi } \\
100 \% \\
-300 \text { Orang }+ \\
\text { Sirkulasi } \\
50 \%\end{array}$ & $\begin{array}{l}-36 \mathrm{~m}^{2} \\
(\text { pembula } \\
\tan ) \\
-24 \mathrm{~m}^{2}\end{array}$ & $\begin{array}{l}\cdot \mathrm{NDA} \\
\cdot \text { An }\end{array}$ \\
\hline 5 & \begin{tabular}{|l|} 
- Tangga \\
Darurat \\
- Staft \\
- Lift Barang \\
- R. Mesin \\
Lift
\end{tabular} & & & $\begin{array}{l}-10 \text { unit } \\
-6 \text { unit } \\
-6 \text { unit } \\
-6 \text { unit }\end{array}$ & $\begin{array}{l}\cdot 200 \mathrm{~m} 2 \\
\cdot-12 \mathrm{~m} 2 \\
\cdot 30 \mathrm{~m} 2 \\
\cdot 30 \mathrm{~m} 2\end{array}$ & $\begin{array}{l}\text { - NDA } \\
\text { - } \text { - NDA } \\
\text { - NDA }\end{array}$ \\
\hline & $\begin{array}{l}\text { - Kios } \\
\text { Souvernir } \\
\text { - Kios } \\
\text { Koran majal } \\
\text { ah } \\
\text { - Kias } \\
\text { Makanan } \\
\text { dan } \\
\text { mimeman } \\
\text { ringan } \\
\text { - Wartel \& } \\
\text { Counter HP } \\
\\
\text { - Agen } \\
\text { Perjalanan }\end{array}$ & & $\begin{array}{l}-0,8 \mathrm{~m}^{2} \\
-0,8 \mathrm{~m}^{2} \\
-0,8 \mathrm{~m}^{2} \\
-0,8 \mathrm{~m}^{2} \\
-0,8 \mathrm{~m} 2\end{array}$ & $\begin{array}{c}-10 \text { Orang } \\
+ \text { Sirkulasi } \\
100 \% \\
-10 \text { Orang } \\
+ \text { Sirkulasi } \\
100 \% \\
-10 \text { Orang } \\
+ \text { Sirkulasi } \\
100 \% \\
\\
-10 \text { Orang } \\
+ \text { Sirkulasi } \\
50 \%+20 \\
\text { box } \\
-15 \text { Orang } \\
+ \text { Sirkulasi } \\
100 \%\end{array}$ & $\begin{array}{c}-8 \mathrm{~m}^{2}+20 \\
\mathrm{~m}^{2}(@ b o x \\
\left.-1 \mathrm{~m}^{2}\right)- \\
28 \mathrm{~m}^{2} \\
-24 \mathrm{~m}^{2}\end{array}$ & - An \\
\hline 5 & $\begin{array}{l}\text { Toilet } \\
\text { - Pria } \\
\text { - Wanita }\end{array}$ & $\begin{array}{l}\text { - Kloset } \\
\text { - Wastafet } \\
\text { - Urinoir }\end{array}$ & $\begin{array}{l}\text { - } a 2,25 \mathrm{~m}^{2} \\
\cdot\left(a 1 \mathrm{~m}^{2}\right. \\
\cdot a 1 \mathrm{~m}^{2}\end{array}$ & $\begin{array}{l}\text { - } 20 \text { unit } \\
-20 \text { unit } \\
-40 \text { unit } \\
\text { - Sirkulasi } 50 \%\end{array}$ & $155 \mathrm{~m}^{2}$ & $\mathrm{An}$ \\
\hline 6 & Loket Pronon & $\begin{array}{l}\text { Meja dan kursi } \\
\text { loket }\end{array}$ & $0,8 \mathrm{~m}^{2}$ & $\begin{array}{l}12 \text { orang } \\
\text { tsirkulai } \\
50 \%\end{array}$ & $\begin{array}{l}15 \mathrm{~m}^{2} \\
\text { (pembulat } \\
\text { an) }\end{array}$ & $\mathrm{NDA}$ \\
\hline 7 & $\begin{array}{l}\text { Penitipan } \\
\text { Barang }\end{array}$ & $\begin{array}{l}\text { Meja dan Kursi } \\
\text { Petugas, Loker, } \\
\text { dan CCTV }\end{array}$ & $0,8 \mathrm{~m}^{2}$ & $\begin{array}{l}200 \text { Orang }+ \\
\text { sirkulasi } 50 \\
\%\end{array}$ & $230 \mathrm{~m} 2$ & $\overline{\mathrm{NDA}}$ \\
\hline 8 & Musholla & $\begin{array}{l}\text { Almari, fissitas } \\
\text { wuxlhu dan sholat }\end{array}$ & $0,8 \mathrm{~m}^{2}$ & $\begin{array}{l}100 \text { Orang + } \\
\text { sitkulasi } \\
50 \%\end{array}$ & $120 \mathrm{~m}^{2}$ & An \\
\hline 9 & \begin{tabular}{|l} 
Sectaray \\
\end{tabular} & $\begin{array}{l}\text { Meja, Kursi, } \\
\text { Monitor CCTV }\end{array}$ & $0,8 \mathrm{~m}^{\prime}$ & \begin{tabular}{|l|}
10 oratg + \\
sirkulasi $100 \%$
\end{tabular} & $16 \mathrm{~m}^{2}$ & An \\
\hline 10 & \begin{tabular}{|l|} 
Tempst \\
Parkit \\
penumpang
\end{tabular} & $\begin{array}{l}\text { Perlengkapan } \\
\text { parkir }\end{array}$ & $\begin{array}{l}\text { mobil }=12,5 \\
\mathrm{~m} 2 \\
\mathrm{spd} \text { motor }= \\
2 \mathrm{~m}^{2}\end{array}$ & $\begin{array}{l}50 \text { mothl } \\
200 \text { spd } \\
\text { motor } \\
+ \text { SSirtulasi } \\
50 \%\end{array}$ & $1540 \mathrm{~mm}^{2}$ & NDA \\
\hline 11 & $\begin{array}{l}\begin{array}{l}\text { Ruang Keschuttan } \\
\text { (Klinikik) }\end{array} \\
\end{array}$ & $\begin{array}{l}\text { Meja, kursi, ranjiang, } \\
\text { almanin, perailatan } \\
\text { keschatan, ban } \\
\text { CCTV }\end{array}$ & $2 \mathrm{~m} 2$ & \begin{tabular}{|l|}
20 orats + \\
sirkulasi $50 \% 6$
\end{tabular} & $60 \mathrm{~m} 2$ & $A_{n}$ \\
\hline \multicolumn{5}{|c|}{ Sub Total } & \multicolumn{2}{|l|}{$3,840 \mathrm{~m}^{2}$} \\
\hline \multicolumn{5}{|c|}{ Sirkulasi antar ruang $30 \%$} & \multicolumn{2}{|l|}{$1,152 \mathrm{~m}^{2}$} \\
\hline \multicolumn{5}{|c|}{ Total keseluruhan fuasan } & \multicolumn{2}{|l|}{$4,992 \mathrm{~m}^{2}$} \\
\hline
\end{tabular}

\section{b. Ruang Operasional Pengelola Terminal}

Tabel 6. Program Besaran Ruang Pengelola Terminal 


\begin{tabular}{|c|c|c|c|c|c|c|}
\hline N & Ruang & $\begin{array}{c}\text { Kebutuhan } \\
\text { Perabot }\end{array}$ & $\begin{array}{c}\text { Pendekatan } \\
\text { / orang }\end{array}$ & Kapasitas & $\begin{array}{l}\text { Luas } \\
\text { Ruang }\end{array}$ & Sumber \\
\hline 1 & Kantor & $\begin{array}{l}\text { Meja, kursi, } \\
\text { Komputer, } \\
\text { almari, dan } \\
\text { CCTV }\end{array}$ & $2 \mathrm{~m}^{2}$ & 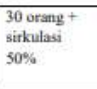 & $90 \mathrm{~m}^{2}$ & An \\
\hline 2 & $\begin{array}{l}\text { Toilet } \\
\text { - Pria } \\
\text { - Wanita }\end{array}$ & $\begin{array}{l}\text { - Kloset } \\
\text { - Wastafel } \\
\text { - Urinoir }\end{array}$ & 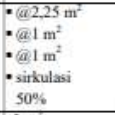 & $\begin{array}{l}6 \text { unit (Pria), } \\
6 \text { Unit } \\
\text { (Wanita) }\end{array}$ & $\begin{array}{l}80 \mathrm{~m}^{2} \\
\text { (pembulatat } \\
\text { n) }\end{array}$ & An \\
\hline 3 & Ruang Rapat & $\begin{array}{l}\text { Meja, kursi, } \\
\text { Komputer, } \\
\text { Layar LCD, } \\
\text { almari }\end{array}$ & $2 m^{2}$ & $\begin{array}{l}\text { S0 orang + } \\
\text { sirkulasi } \\
50 \%\end{array}$ & $150 \mathrm{mt}^{2}$ & An \\
\hline 4 & Dapur & $\begin{array}{l}\text { Meja, kursi, } \\
\text { peralatan } \\
\text { memasak }\end{array}$ & $0,8 \mathrm{~m}^{2}$ & $\begin{array}{l}10 \text { orang }+ \\
\text { sirkulasi } \\
50 \%\end{array}$ & $12 \mathrm{~m}^{2}$ & NDA \\
\hline 5 & Musbolla & $\begin{array}{l}\text { Alman, } \\
\text { fasilitas wudhu dan } \\
\text { sholat }\end{array}$ & $0,8 \mathrm{~m}^{2}$ & $\begin{array}{l}20 \text { oratang }+ \\
\text { sirkulasi } \\
50 \%\end{array}$ & $24 \mathrm{~m}^{2}$ & An \\
\hline 6 & \begin{tabular}{|l} 
Tempat parkir \\
petugas
\end{tabular} & $\begin{array}{l}\text { Perlengkapan } \\
\text { parkir }\end{array}$ & $\begin{array}{l}\begin{array}{l}\text { mobil }=12,5 \\
\mathrm{~m}^{2} \\
\text { spd motor }= \\
2 \mathrm{~m}^{2}\end{array} \\
\end{array}$ & $\begin{array}{l}20 \text { mobili, } 30 \\
\text { spd mokot + } \\
\text { sirkulasi } \\
50 \% \\
\end{array}$ & $526 \mathrm{~m}^{2}$ & $\begin{array}{l}\text { An+ } \\
\text { NDA }\end{array}$ \\
\hline 7 & \begin{tabular}{|l|} 
Ruangan alat- \\
alat kebersihan
\end{tabular} & $\begin{array}{l}\text { Perlengkapain } \\
\text { alat-alat } \\
\text { kebersihan }\end{array}$ & $0,8 \mathrm{~m}^{2}$ & $\begin{array}{l}15 \text { Orang + } \\
\text { sirkulasi } \\
50 \%\end{array}$ & $18 \mathrm{~m}^{2}$ & $\begin{array}{l}\mathrm{An+} \\
\mathrm{NDA}\end{array}$ \\
\hline 8 & $\begin{array}{l}\text { Ruangan alat. } \\
\text { alat M.E. }\end{array}$ & $\begin{array}{l}\text { Pertongkapan } \\
\text { alat-alat M.E. }\end{array}$ & $0.8 \mathrm{~m}^{2}$ & $\begin{array}{l}\text { To neang }+ \\
\text { sirkulasi } \\
50 \%\end{array}$ & $\begin{array}{l}12 \mathrm{~m}^{2} \\
\text { (pembulat } \\
\text { an) }\end{array}$ & NDA \\
\hline 9 & \begin{tabular}{|l|} 
Menara \\
pengawas
\end{tabular} & $\begin{array}{l}\text { Meja, kursi, } \\
\text { Komputer, } \\
\text { almari, dan } \\
\text { CCTV }\end{array}$ & $2 \mathrm{~m}^{2}$ & $\begin{array}{l}5 \text { orang }+ \\
\text { sirkulasi } \\
50 \%\end{array}$ & $15 \mathrm{~m}^{2}$ & $\begin{array}{l}\mathrm{An}+ \\
\mathrm{NDA}\end{array}$ \\
\hline \multicolumn{3}{|c|}{ Sub Total } & \multicolumn{4}{|c|}{$927 \mathrm{~m}^{2}$} \\
\hline \multicolumn{3}{|c|}{ Sirkulasi antar ruang $30 \%$} & \multicolumn{4}{|c|}{$278 \mathrm{~m}^{2}$} \\
\hline \multicolumn{4}{|c|}{ Total keseluruhan luasan } & \multicolumn{2}{|c|}{$1,205 \mathrm{~m}^{2}$} & \\
\hline
\end{tabular}

\section{c. Ruang Operasional Armada Bus}

Tabel 7. Program Besaran Ruang Armada Bus

\begin{tabular}{|c|c|c|c|c|c|c|}
\hline No & Ruang & $\begin{array}{c}\text { Kebutahan } \\
\text { Perabot }\end{array}$ & $\begin{array}{c}\text { Pendekatan } \\
\text { / orang }\end{array}$ & Kapasitas & $\begin{array}{l}\text { Laas } \\
\text { Ruang }\end{array}$ & Sumber \\
\hline 1 & $\begin{array}{l}\text { Parkir /ngetem } \\
\text { - Bus } \\
\text { - Angkutan } \\
\text { umum } \\
\text { - motor }\end{array}$ & $\begin{array}{l}\text { Tempat } \\
\text { parkir }\end{array}$ & $\begin{array}{l}\text { Bus }=50 \mathrm{~m}^{2} \\
\text { Angkutan } \\
\text { Uimum = } \\
12,5 \mathrm{~m}^{2} \\
\text { Motor }=6 \\
\mathrm{~m} 2\end{array}$ & \begin{tabular}{|l} 
- Bus $=40$ \\
- Angkutan \\
Umum $=$ \\
250 \\
- Motor $=200$ \\
- Sirkulasi \\
$50 \%$ \\
\end{tabular} & $9,487 \mathrm{~m}^{2}$ & $\begin{array}{l}\begin{array}{l}\mathrm{NDA}+ \\
\mathrm{An}\end{array} \\
\end{array}$ \\
\hline 2 & $\begin{array}{l}\text { Peron } \\
\text { keberangkatan } \\
\text { - Bus } \\
\text {-Angkutan } \\
\text { umum }\end{array}$ & & $\begin{array}{l}\text { Bus }=50 \mathrm{~m}^{2} \\
\text { Angkutan } \\
\text { Umum }= \\
12,5 \mathrm{~m}^{2}\end{array}$ & $\begin{array}{l}\text { - Sirkulasi } \\
=50 \% \\
\text { - Bus }=10 \\
\text { - Angkutan } \\
\text { Unum }=20\end{array}$ & $1,125 \mathrm{~m}^{2}$ & $\begin{array}{l}\mathrm{NDA}+ \\
\mathrm{An}\end{array}$ \\
\hline 3 & $\begin{array}{l}\text { Peron Kedatangan } \\
\text { - Bus } \\
\text { - Angkutan } \\
\text { umum }\end{array}$ & & $\begin{array}{l}\text { Bus }=50 \mathrm{~m}^{2} \\
\text { Angkutan } \\
\text { Umum }= \\
12,5 \mathrm{~m}^{2}\end{array}$ & $\begin{array}{l}\text { - Sirkulasi } \\
=50 \% \\
\text { - Bus }=10 \\
\text { - Angkutan } \\
\text { Unum }=20\end{array}$ & $1.125 \mathrm{~m}^{2}$ & $\begin{array}{l}\mathrm{NDA}+ \\
\mathrm{An}\end{array}$ \\
\hline 4 & $\begin{array}{l}\text { Bengkel } \\
\text { - Bus } \\
\text { - Angkutan } \\
\text { umum }\end{array}$ & $\begin{array}{l}\text { Peralatan } \\
\text { standar } \\
\text { bengkel }\end{array}$ & $\begin{array}{l}\text { Bus }=50 \mathrm{~m}^{2} \\
\text {-Angkutan } \\
\text { Umum }= \\
12,5 \mathrm{~m}^{2}\end{array}$ & $\begin{array}{l}\text { - Bus }=10 \\
\text { - Angkutan } \\
\text { Umsim }=20 \\
\text { - Sirkulasi } \\
=50 \%\end{array}$ & $1,125 \mathrm{~m}^{2}$ & $\begin{array}{l}\mathrm{NDA}+ \\
\mathrm{An}\end{array}$ \\
\hline 5 & $\begin{array}{l}\text { Pencucian } \\
\text { - Bus } \\
\text {-Angkutan umum }\end{array}$ & $\begin{array}{l}\text { Peralatan } \\
\text { standar cuei } \\
\text { mobil }\end{array}$ & $\begin{array}{l}\text { - Bus }=50 \mathrm{~m}^{2} \\
\text { Angkvotan } \\
\text { Umum }=12,5 \\
\mathrm{~m}^{2}\end{array}$ & $\begin{array}{l}\text { - Bus }=10 \\
\text { - Angkutan } \\
\text { Umum }=20 \\
\text { - Sirkulasi } \\
\text { - }=50 \%\end{array}$ & $\begin{array}{l}1,125 \mathrm{~m}^{2} \\
\text { (Pembulat } \\
\text { an) }\end{array}$ & $\begin{array}{c}\mathrm{NDA}^{+} \\
\mathrm{An}\end{array}$ \\
\hline 6 & Musholla Armada & & $0,8 \mathrm{~m}^{2}$ & $\begin{array}{l}100 \text { onang }+ \\
\text { sirkulasi } \\
50 \%\end{array}$ & $120 \mathrm{~m}^{2}$ & $\begin{array}{l}\mathrm{NDA}+ \\
\mathrm{An}\end{array}$ \\
\hline 7 & Mess Armada & $\begin{array}{l}\text { Fasilitas } \\
\text { peristirahatan }\end{array}$ & $3 \mathrm{~m}^{2}$ & \begin{tabular}{|l}
70 orang + \\
girkulasi \\
$50 \%$
\end{tabular} & $315 \mathrm{~m}^{2}$ & $\begin{array}{l}\mathrm{NDA}^{+} \\
\mathrm{An}\end{array}$ \\
\hline \multicolumn{4}{|c|}{ Sub Total } & \multicolumn{3}{|c|}{$14,422 \mathrm{~m}^{2}$} \\
\hline \multicolumn{4}{|c|}{ Sirkulasi antar ruang $30 \%$} & \multicolumn{2}{|c|}{$3,326 \mathrm{~m}^{2}$} & \\
\hline \multicolumn{4}{|c|}{ Total keseluruhan luasan } & \multicolumn{2}{|c|}{$18,748 \mathrm{~m}^{2}$} & \\
\hline
\end{tabular}

Tabel 8. Program Besaran Ruang Area Komersial/Mall

\begin{tabular}{|c|c|c|c|c|c|c|}
\hline No & Ruang & $\begin{array}{c}\text { Kebutuhan } \\
\text { Perabot }\end{array}$ & $\begin{array}{l}\text { Pendekatan } \\
\text { / orang }\end{array}$ & Kapasitas & $\begin{array}{l}\text { Luas } \\
\text { Ruang }\end{array}$ & Sumber \\
\hline \multicolumn{7}{|c|}{ Program Ruang Anchor Tenant } \\
\hline 1 & $\begin{array}{l}\text { Department Store } \\
\text { - Area belanja }\end{array}$ & meja & $-2 \mathrm{~m}^{2}$ & $\begin{array}{l}-250 \text { Orang + } \\
\text { Sirkulasi } \\
50 \% 6\end{array}$ & $-1000 \mathrm{~m}^{2}$ & $\begin{array}{l}\mathrm{NDA}+ \\
\mathrm{An}\end{array}$ \\
\hline 2 & $\begin{array}{l}\text { Supermarket } \\
\text { - Area belanja }\end{array}$ & $\begin{array}{l}\text { Meja kasir, kursi, rak } \\
\text { tralase }\end{array}$ & $\mathrm{k} \cdot 2 \mathrm{~m}^{2}$ & $\begin{array}{l}-250 \text { Orang + } \\
\text { Sirkulasi } \\
50 \%\end{array}$ & $1000 \mathrm{~m} 2$ & $\begin{array}{l}\mathrm{NDA}+ \\
\mathrm{An}\end{array}$ \\
\hline 3 & \begin{tabular}{|l} 
cineplex \\
- R.Penonton \\
- R.Tiket \\
- R.Proyckortor \\
- R.Penyimpanan \\
- Hall \\
- Tollet Pria \\
- Toilet Wanita
\end{tabular} & $\begin{array}{l}\text { Kuri } \\
\text { Meja, kursi } \\
\text { Meja } \\
\text { Kursi } \\
\text { Kloset, urinoir } \\
\text { Kloset,wastavel }\end{array}$ & $\begin{array}{l}0,8 \mathrm{~m} 2 \\
0,8 \mathrm{~m} 2 \\
0,1 \mathrm{~m} 2 \\
0,8 \mathrm{~m} 2 \\
-3 \mathrm{~m} 2 \\
-3 \mathrm{~m} 2\end{array}$ & $\begin{array}{l}-150 \text { orang } \\
-4 \text { Orang } \\
-2 \text { Orang } \\
-4 \text { Orang } \\
-1 \text { unit } \\
-1 \text { unit } \\
+ \text {-sirkulasi } 50 \%\end{array}$ & $\begin{array}{l}\cdot 250 \mathrm{~m} 2 \\
\cdot 10 \mathrm{~m} 2 \\
\cdot 30 \mathrm{~m} 2 \\
\cdot 60 \mathrm{~m} 2 \\
\cdot 60 \mathrm{~m} 2 \\
\cdot 24 \mathrm{~m} 2 \\
\cdot 24 \mathrm{~m} 2\end{array}$ & $\begin{array}{l}\mathrm{NDA}+ \\
\mathrm{An}\end{array}$ \\
\hline 4 & $\begin{array}{l}\text { Game center } \\
\text { - Area bermain } \\
\text { - Ruang tiket }\end{array}$ & & $0,8 \mathrm{~m} 2$ & $\begin{array}{l}\text { : } 60 \text { orang } \\
-2 \text { orang } \\
\text { +sizkulasi } 50 \%\end{array}$ & $\begin{array}{l}=150 \mathrm{~m} 2 \\
\cdot 2,5 \mathrm{~m} 2\end{array}$ & $\begin{array}{l}\mathrm{NDA}+ \\
\mathrm{An}\end{array}$ \\
\hline 5 & $\begin{array}{l}\text { Book store } \\
\text { - Area belanja }\end{array}$ & & $2 \mathrm{~m} 2$ & $\begin{array}{l}\text { - } 100 \text { orang } \\
\text { tsirkulasi } 50 \%\end{array}$ & $-400 \mathrm{~m} 2$ & $\underset{\mathrm{An}}{\mathrm{NDA+}}$ \\
\hline 6 & \begin{tabular}{|l|} 
Foodcourt \\
- Area makan \\
- Counter dan \\
dapur \\
- toilet \\
\end{tabular} & & $\begin{array}{l}-1,5 \mathrm{~m} 2 \\
-3 \mathrm{~m} 2 \\
\end{array}$ & $\begin{array}{l}.50 \text { orang } \\
.3 \text { unit } \\
.1 \text { unit } \\
\end{array}$ & $\begin{array}{l}-100 \mathrm{~m} 2 \\
-60 \mathrm{~m} 2 \\
-24 \mathrm{~m} 2 \\
\end{array}$ & $\begin{array}{l}\mathrm{NDA}+ \\
\mathrm{An}\end{array}$ \\
\hline 7 & \begin{tabular}{|l|} 
Restaurant \\
- R.makan \\
- Counter dan \\
dapur \\
- Toilet
\end{tabular} & & $\begin{array}{l}-2 \mathrm{~m} 2 \\
-3 \mathrm{~m} 2\end{array}$ & $\begin{array}{l}\text { : } 50 \text { orang } \\
-2 \text { unit } \\
\text { - } 1 \text { unit } \\
+ \text { sirkulasi } 50 \%\end{array}$ & $\begin{array}{l}\cdot 100 \mathrm{~m} 2 \\
-60 \mathrm{~m} 2 \\
\cdot 24 \mathrm{~m} 2\end{array}$ & $\begin{array}{l}\mathrm{NDA}+ \\
\mathrm{An}\end{array}$ \\
\hline 8 & \begin{tabular}{|l|} 
Cofe shop \\
- Area duduk \\
- Counter dan \\
dapur
\end{tabular} & & & $\begin{array}{l}: 30 \text { orang } \\
\cdot 1 \text { unit } \\
.11 \text { unit }\end{array}$ & $\begin{array}{l}-50 \mathrm{~m} 2 \\
-25 \mathrm{~m} 2 \\
-24 \mathrm{~m} 2\end{array}$ & $\begin{array}{l}\mathrm{NDA}+ \\
\mathrm{An}\end{array}$ \\
\hline
\end{tabular}

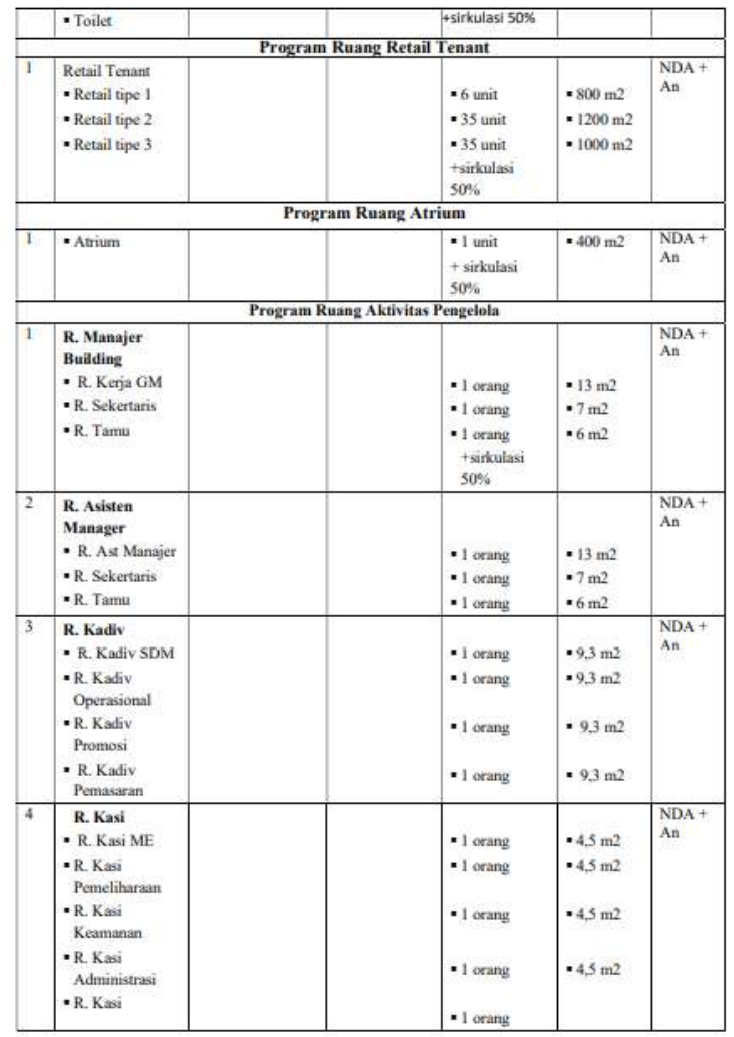

\section{d. Area komersil/Mall}




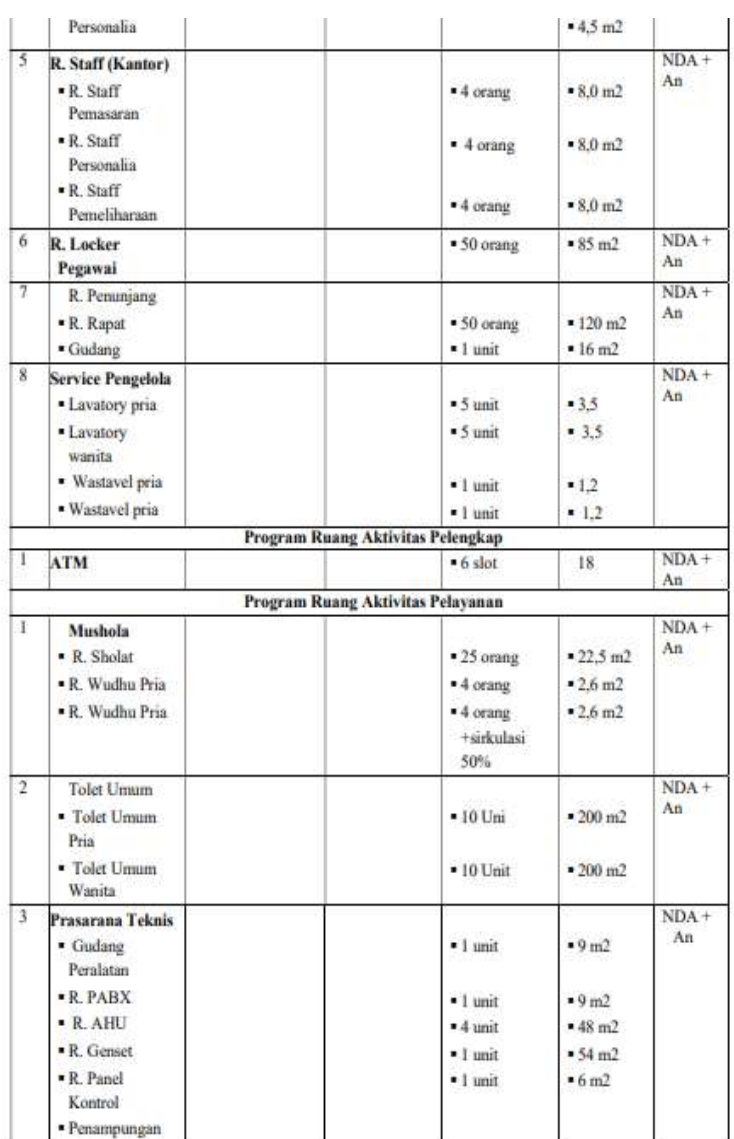

\begin{tabular}{|c|c|c|}
\hline $\begin{array}{l}\text { Sampah } \\
\text { - R. Pormpa } \\
\text { - Reservoir } \\
\text { - R. MDP } \\
\text { - Tangga Darurat } \\
\text { - Shaft } \\
\text { - Lift Barang } \\
\text { - R. Mesin Lift } \\
\text { - R. Mesin AC } \\
\text { - R Jasas }\end{array}$ & $\begin{array}{l}.1 \text { unit } \\
.1 \text { unit } \\
.1 \text { unit } \\
.1 \text { unit } \\
.5 \text { unit } \\
.2 \text { unit } \\
.2 \text { unit } \\
.2 \text { unit } \\
.1 \text { unit } \\
.1 \text { unit }\end{array}$ & $\begin{array}{l}-9 \mathrm{~m} 2 \\
.64 \mathrm{~m} 2 \\
.64 \mathrm{~m} 2 \\
.20 \mathrm{~m} 2 \\
.75 \mathrm{~m} 2 \\
.4 \mathrm{~m} 2 \\
.10 \mathrm{~m} 2 \\
.10 \mathrm{~m} 2 \\
.48 \mathrm{~m} 2 \\
.6 \mathrm{~m} 2\end{array}$ \\
\hline \multicolumn{3}{|l|}{ Sub Total } \\
\hline \multicolumn{2}{|c|}{ Sirkulasi antar ruang $30 \%$} & $2,437 \mathrm{~m}^{2}$ \\
\hline \multicolumn{2}{|c|}{ Total keseluruhan luasan } & $10,562 \mathrm{~m}^{2}$ \\
\hline
\end{tabular}

021

\section{PEMBAHASAN}

Analisa Site

Pemilihan pemintakan public didasari oleh banyaknya sisi yang dapat di akses dan berbatasan area public yang ada yaitu jalan, sedangkan semi public yaitu area yang hanya dapat di akses oleh pengguna tertentu yaitu Penumpang bus. Pada tapak ini terletak pada Jl. Perintis Kemerdekaan No.20 Pudakpayung Kec. Banyumanik Kota Semarang, Jawa Tengah 50265.
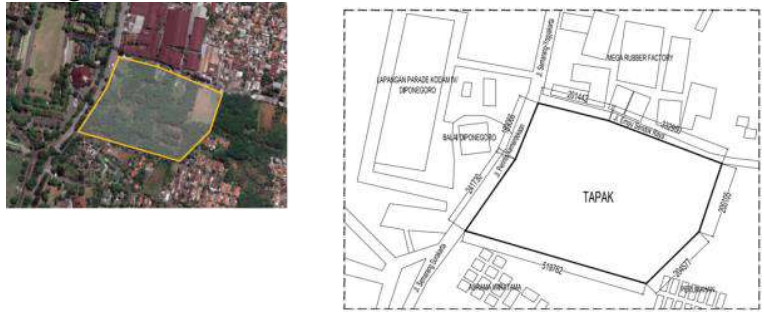

Gambar 1. Tapak

Hasil konsep tapak dapat diperoleh beberapa hal dari analisa yang sudah dibuat meliputi :

- $\quad$ Tapak masih berupa lahan kosong - Penempatan massa memaksimalkan ruang terbuka hijau guna pemanfaatan sirkulasi udara alami dan pencahaya

- Bentuk massa saling berhubungan antara massa 1 dengan lainya agar saling terkoneksi,karena berupa bangunan yang berbasis industry,penelitian dan akademisi

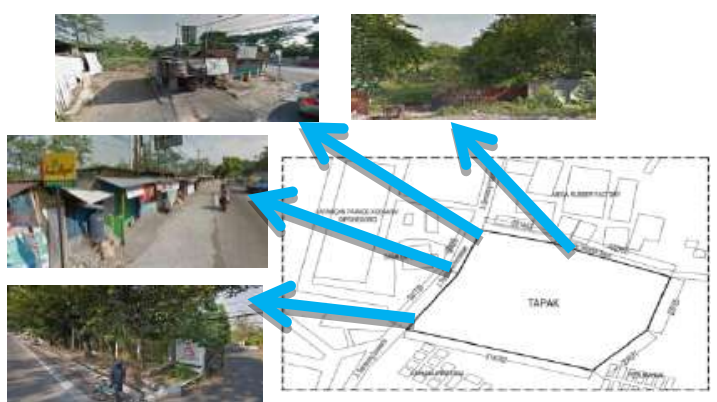

Gambar 2. Analisa Site

Kondisi eksisting pada tapak terpilih sebagai berikut:

Batas-batas Tapak

Utara : Jl.Empu sendok raya, Bangunan pemerintahan dan perumahan

Selatan : Asrama dan perumahan

Timur : Lahan kosong dan perumahan

Barat : Jalan semarang - surakarta 


\section{Konsep Luasan Tapak}

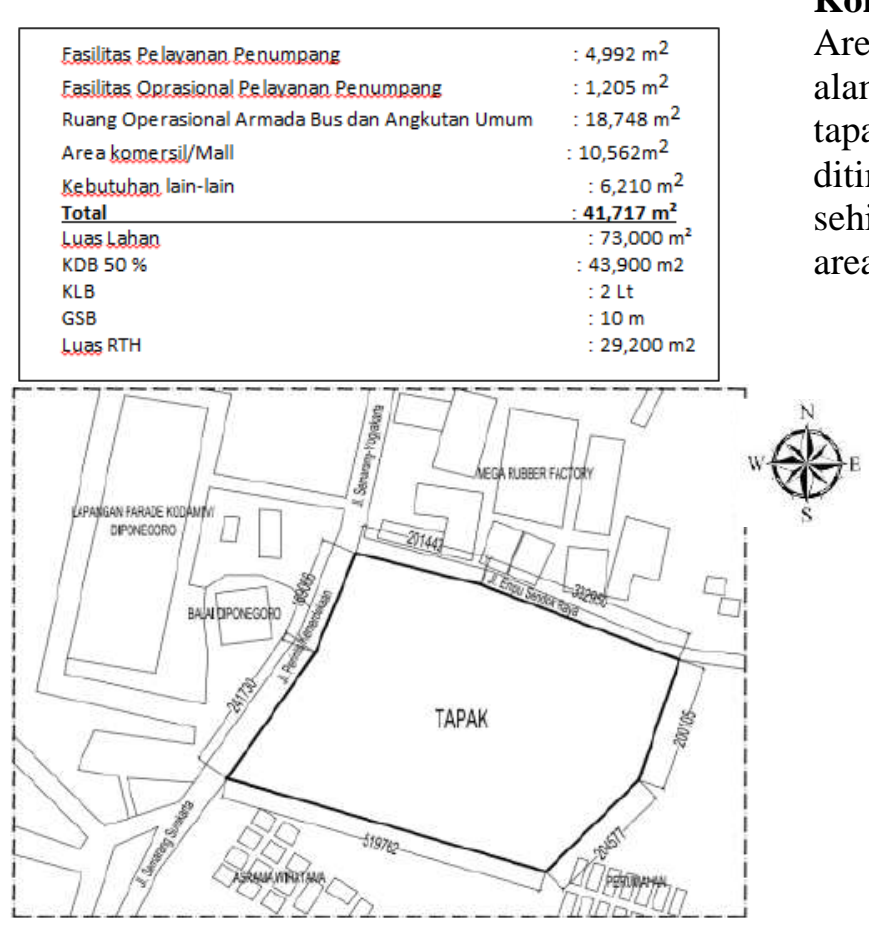

Gambar 3. Konsep Luasan Tapak

\section{Konsep Kebisingan}

Lokasi berada di Jl. OPerintis Kemerdekaan No.20 Pudakpayung0 Kec. Banyumanik Kota 0Semarang, Jawa Tengah 50265. dengan luas lahan $7.3 \mathrm{H}$, dengan arah orientasi menghadap ke timur, dengan batasan tapak sebagai berikut: Di Jl. Perintis Kemerdekaan \& Jl.Semarang-Surakarta kebisingan tinggi karena jalan akses kota dan dua arah, karena hanya dilewati kendaraan ringan dan akses jalan usaha tani menuju persawahan.

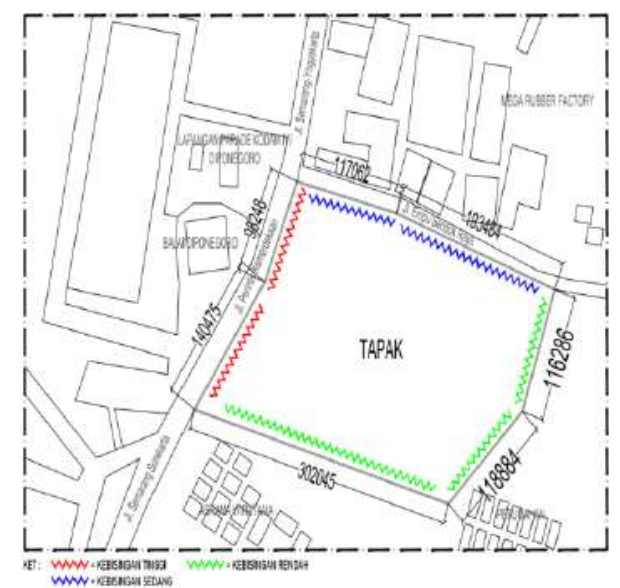

Gambar 4. Konsep Kebisingan

\section{Konsep Klimatologi}

Area yang paling banyak menerima cahaya alami matahari adalah pada sisi timur dan barat tapak, namun panas matahari yang ditimbulkan berdampak pada bangunan sehingga perlu adanya rancangan khusus pada area ini.

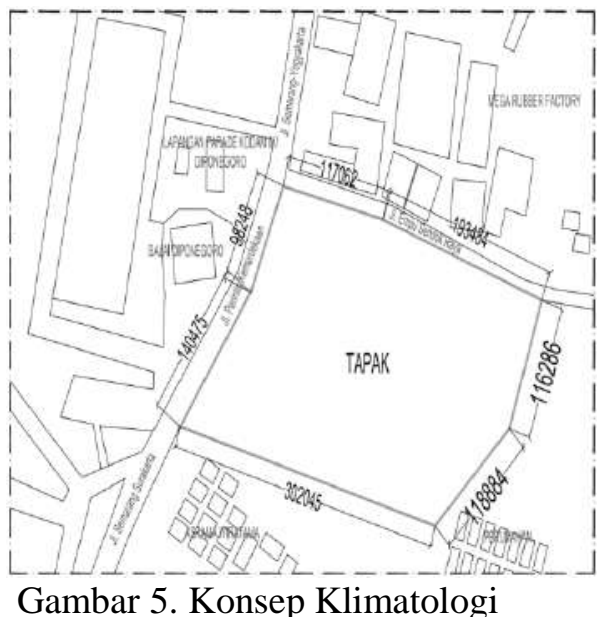

\section{Konsep Angin0}

Angin Obergerak dari arah barat daya menuju timur0 laut suhu udara berkisar $20,60^{\circ} \mathrm{C}$ $34,20^{\circ} \mathrm{C}$ curah hujan terendah $5 \mathrm{~mm} 3$ dan tertinggi $1122 \mathrm{~mm} 3$,kelembapan udara berkisar antara $50 \% 0$ hingga $80 \%$. Sumber: BMKG sisi barat daya tapak mendapatkan cukup angina untuk0 pertukaran Oudara jika diletakkan massamaka angina akan terhalang bangunan dapat menjadi permasalahan desain. Membentuk jalur pergerakan angin agar masuk sampai dalam bangunan supaya memberikan kenyamanan didalam ruangan. 


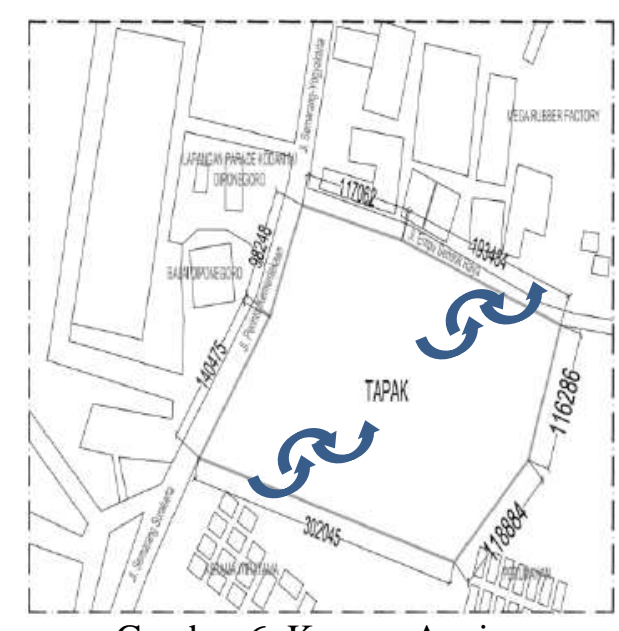

Gambar 6. Konsep Angin

\section{Konsep Aksebilitas}

Jalan Peristis Kemerdekaaan memiliki lebar jalan 20 meter dengan bahu jalan lebar 1 meter memiliki 2 lajur arah berbeda. 0Jalan ini dapat Odilalui 0oleh 0kendaraan roda dua (sepeda motor), empat (mobil, angkutan umum) dan beroda lebih dari empat (bis, truck) serta akses jalan tersebut Jl. Semarang-Surakarta. Akses masuk dan keluar dibuat 2 arah yaitu untuk in/out untuk sirkulasi terminal agar tidak terjadi kemacetan diarea tapak terminal.

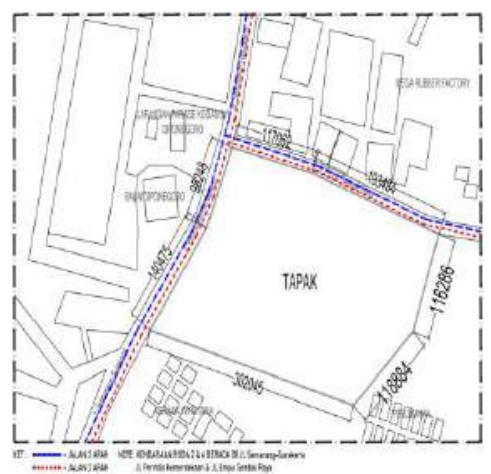

Gambar 7. Konsep Aksebilitas

\section{Konsep View}

Penggunaan view terdapat 3 arah yang dapat digunakan untuk fasade yaitu view utama di J1. Perintis Kemerdekaan di sebelah utara dan selatan tapak terdapat jalan gang kecil serta sebelah timur terdapat lahan. View arah utara dan selatan digunakan untuk area samping bangunan karena view tersebut sangat kurang cocok.

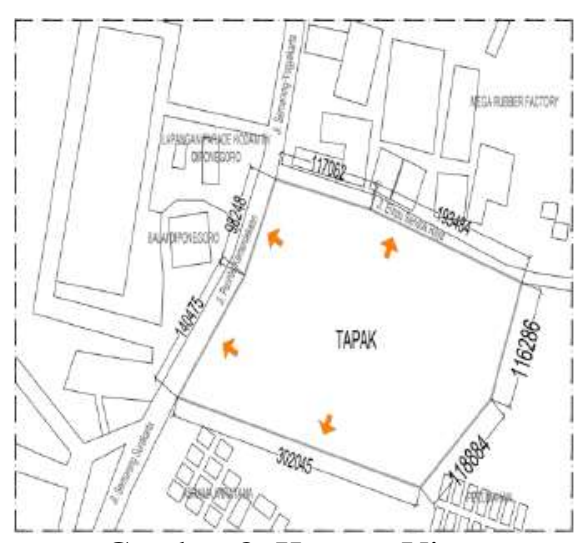

Gambar 8. Konsep View

\section{Konsep Utilitas}

Untuk utilitas exsisting sudah terdapat saluran roil kota. Bagian sisi selatan ke utara dan kondisi jalan agak landau dari drainase yang agak kecil. Jaringan drainase disekitar tapak perlu diperbaiki guna tidak terjadi genangan air,saat terjadi peluapan air dan meninggikan elevasi tapak.

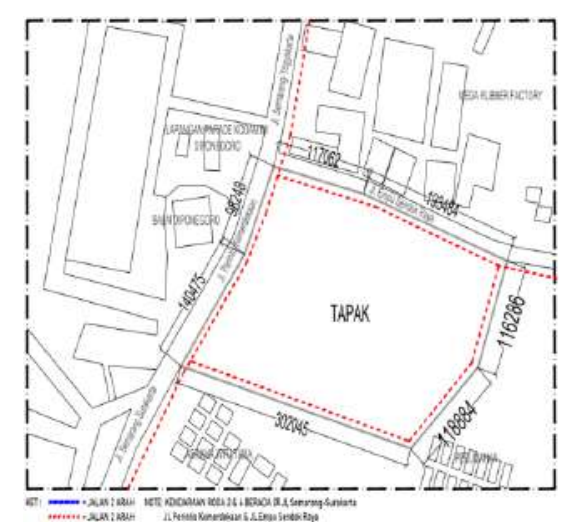

Gambar 9. KonsepUtilitas

\section{Konsep Vegetasi}

Di luar sekitar tapak terdapat pohon liar dan rumput sekitar tapak tidak terawat lagi ini perlu ada penanaman pohon kembali. Lahan sisi utara serta selatan yaitu perumahan dan pabrik. Untuk bagian barat lahan kosong ,sehingga penanganan air hujan dapat dilakukan meode resapan ataupun pengolahan air sesuai dengan fungsinya. 


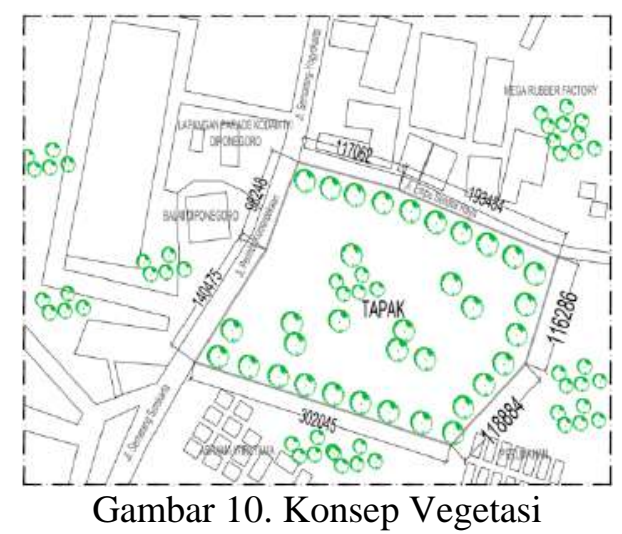

\section{Konsep Penataan Gubahan Massa}

Peletakan gubahan massa pada terminal ini mengambil dari sistem sirkulasi pada terminal yaitu sistem grid, untuk bangunan utama berada di tengah kawasan terminal sedangkan untuk sirkulasi kendaraan bus atau kendaraan umum mengelilingi tapak dan untuk mall itu sendiri berada di belakang gedung utama yang menjadi pusat pembelanjaan pada saat berada di terminal.
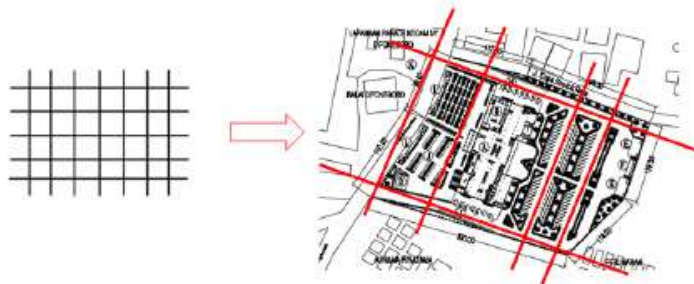

Gambar 11. Konsep Penataan Gubahan Massa

\section{Konsep Fasade/Tampak}

Untuk konsep fasade atau tamapk depan terminal ini yaitu menggunakan konsep ombak, pada bangunan terminal berbentuk gelombang ombak kecil seujung bangunan serta peron yang mempunyai atap bergelombang sedangkan untuk bangunan mall yang mempunyai lantai tinggi dibuat ombak yang menjulang tinggi.

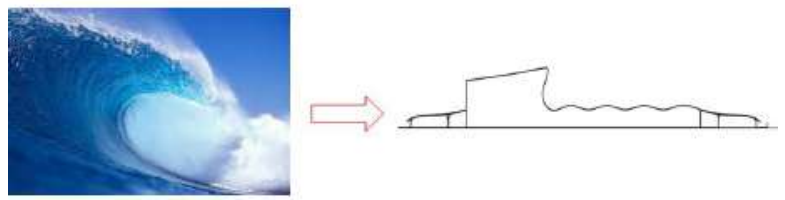

Gambar 12. Konsep Fasade/Tampak Sumber: 


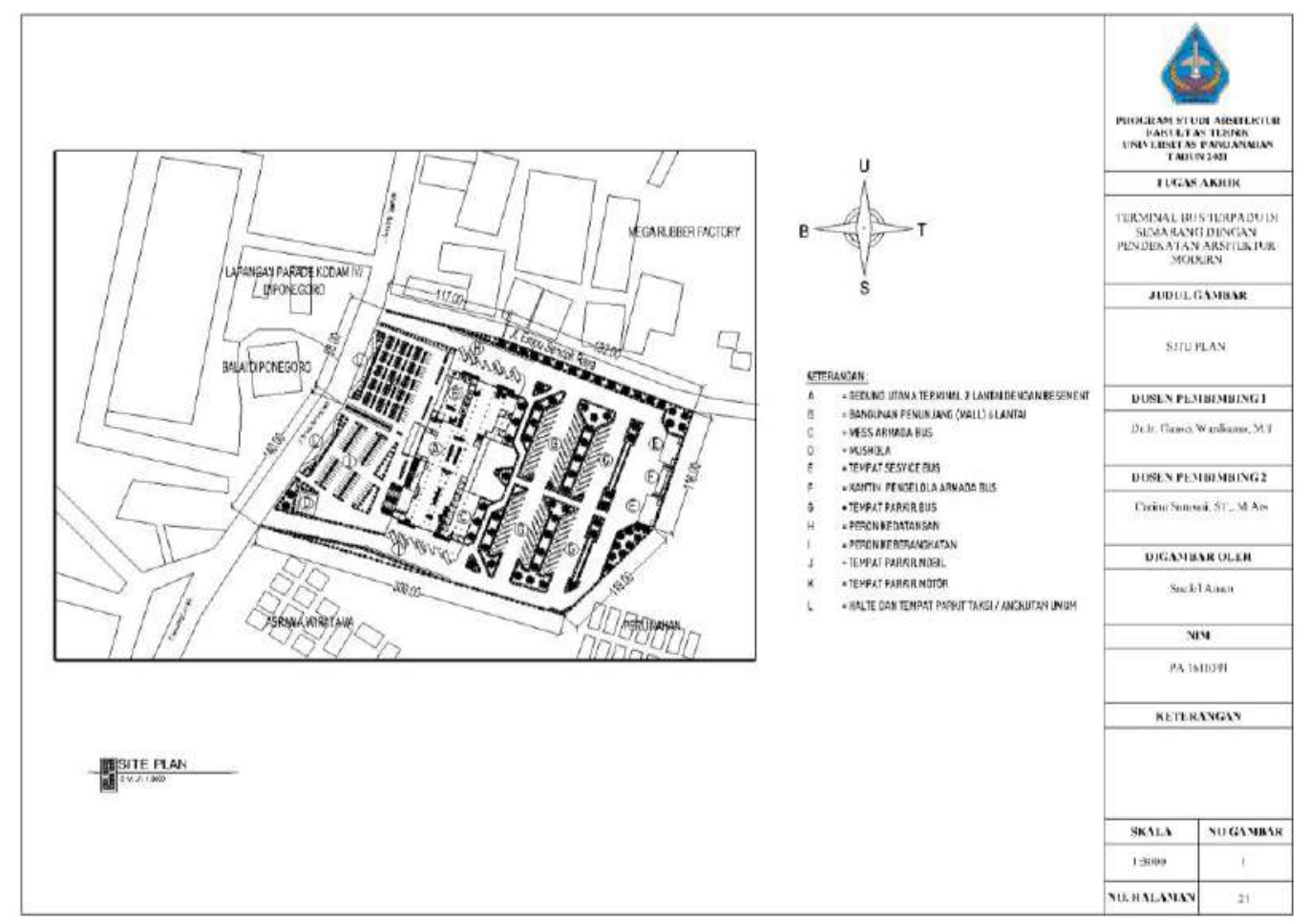

Gambar 13. Site Plan

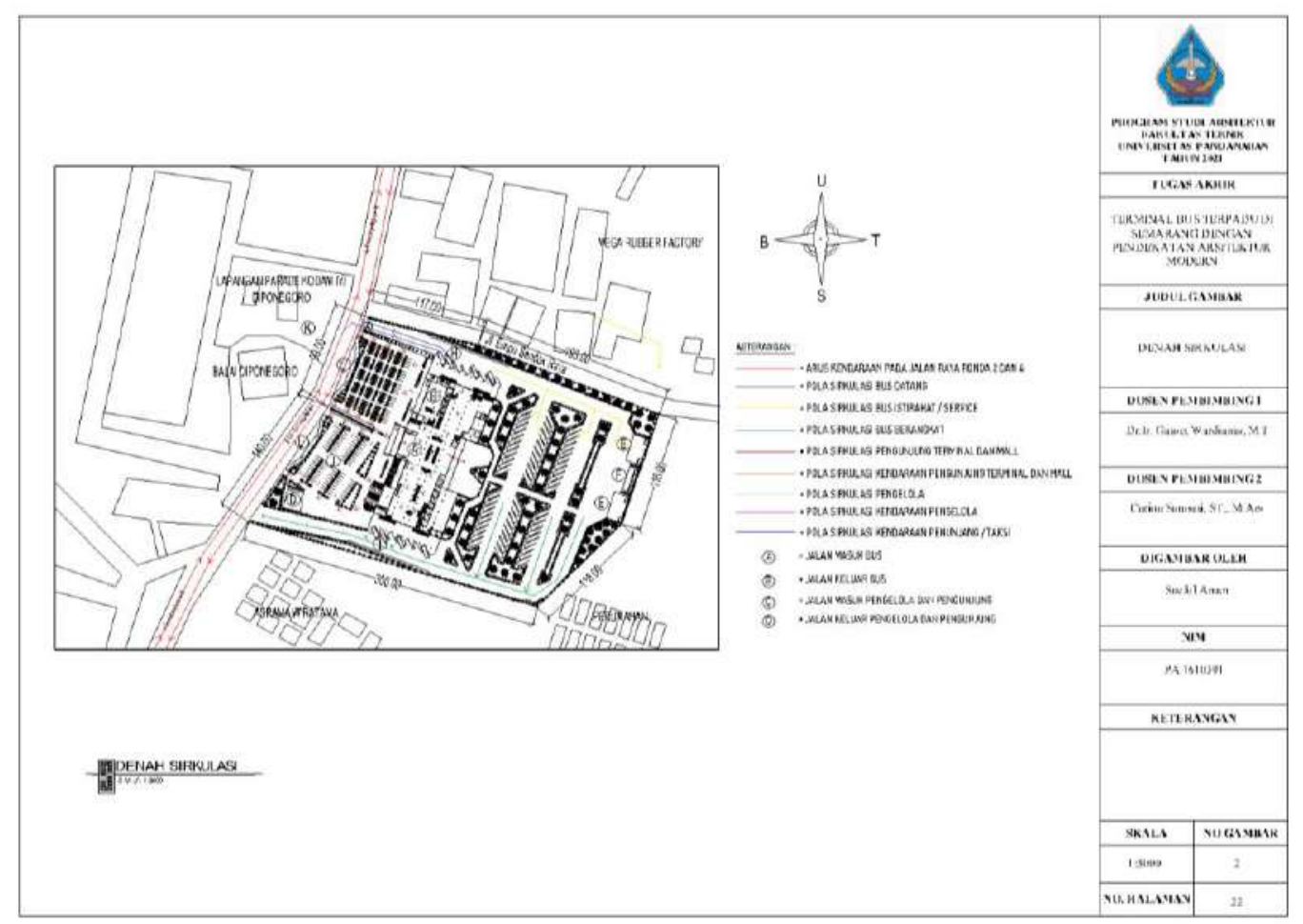

Gambar 14. Denah Sirkulasi 


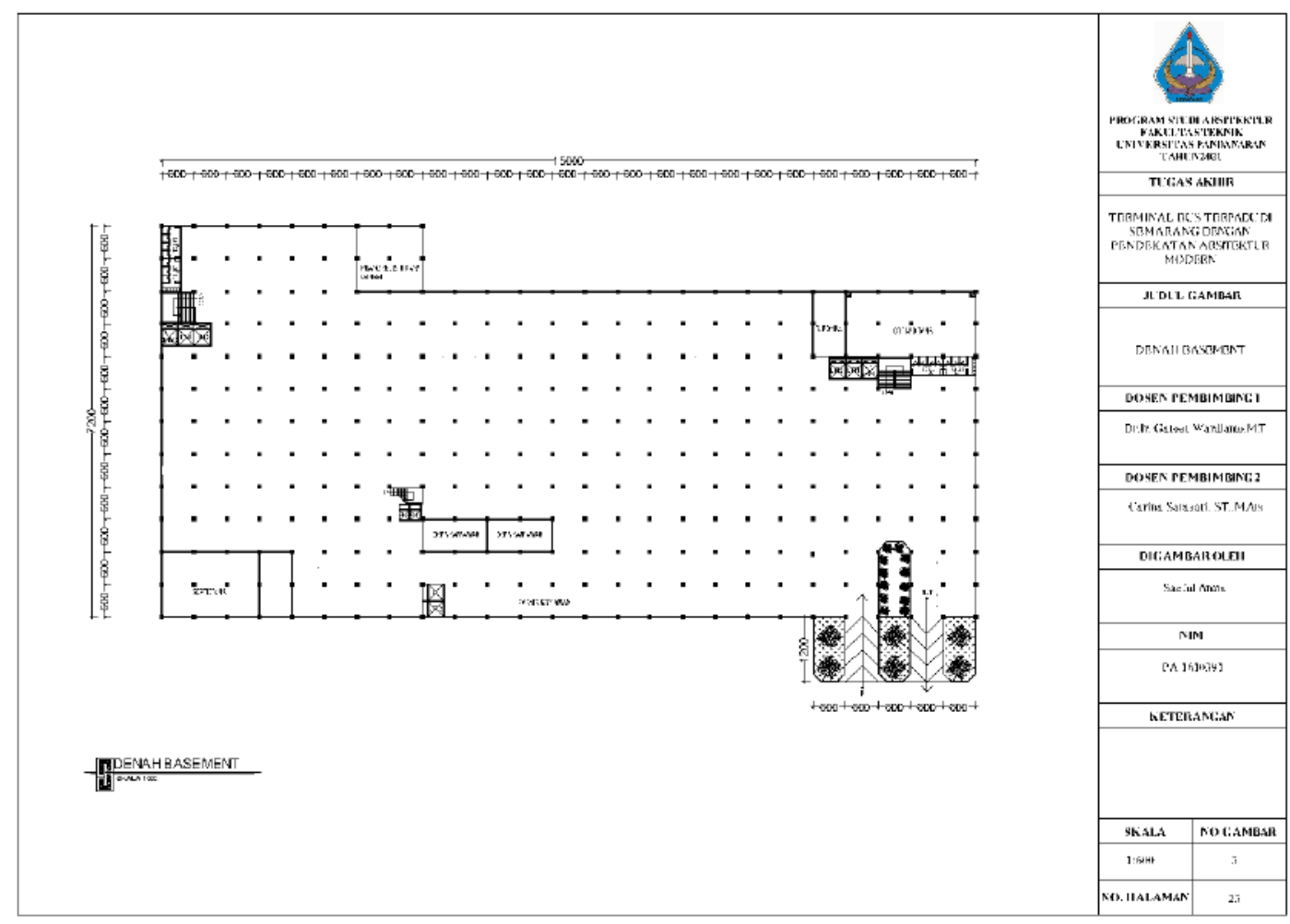

Gambar 15. Denah Basement

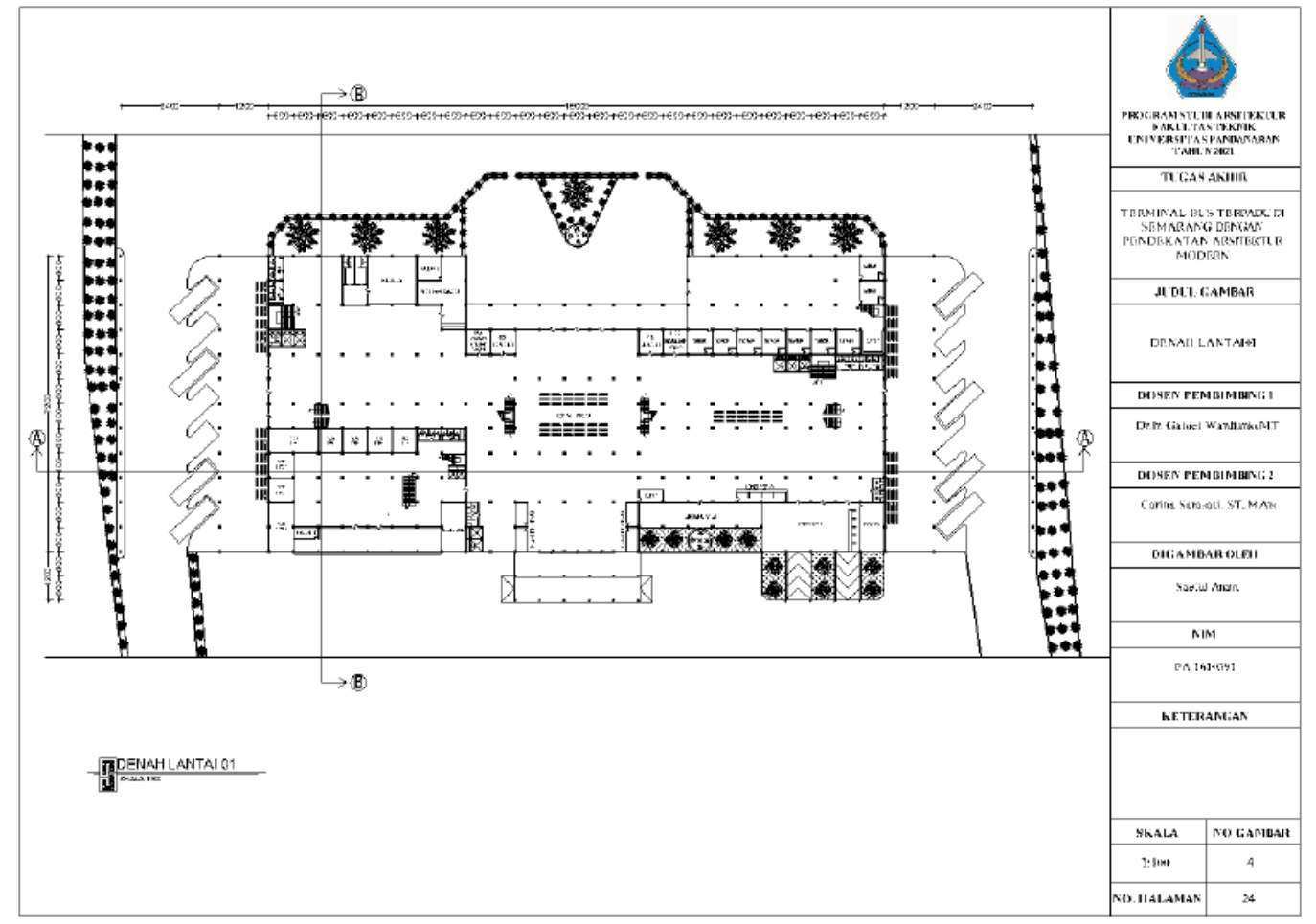

Gambar 16. Denah Lantai 01 


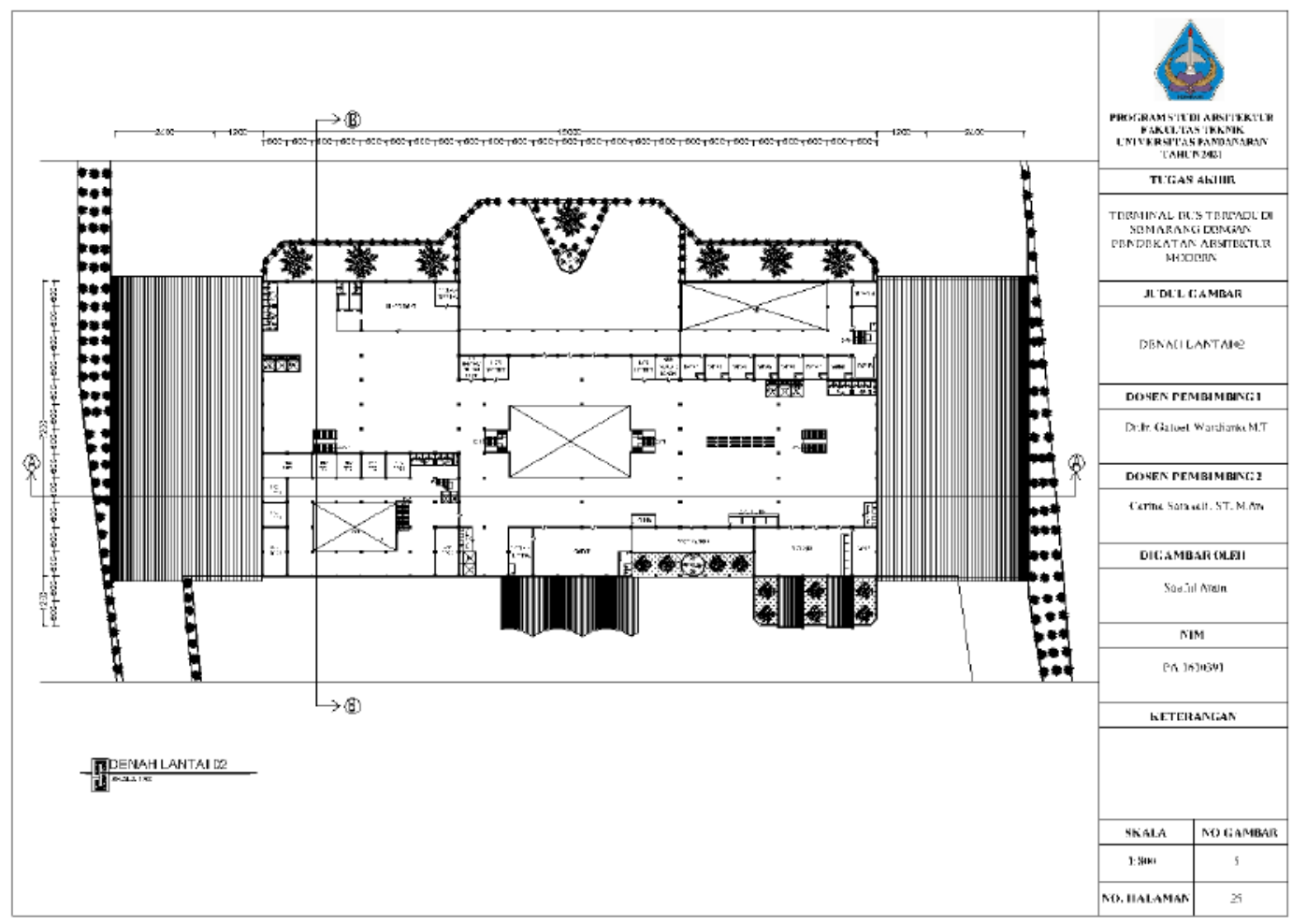

Gambar 17. Denah Lantai 02

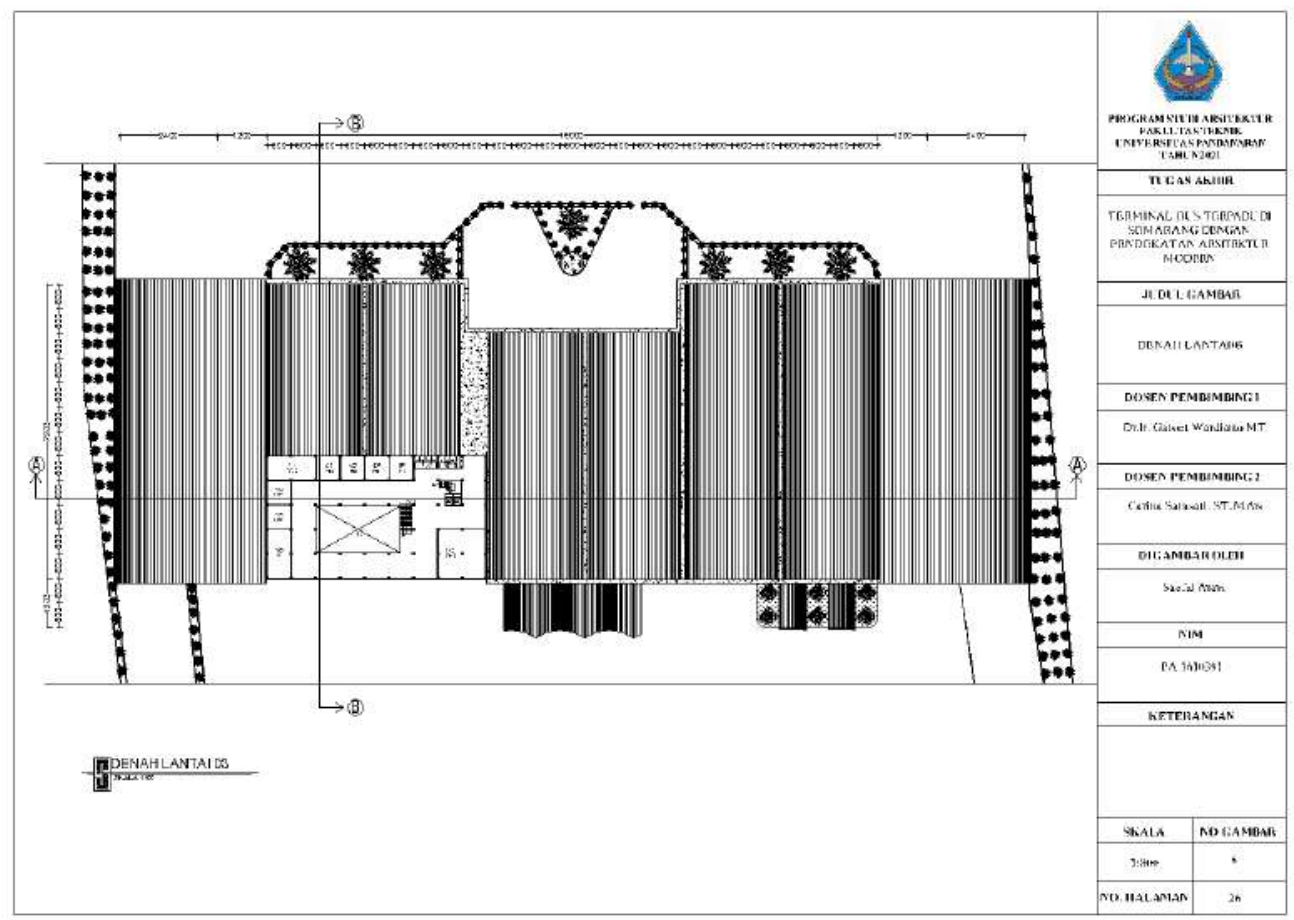

Gambar 20. Denah Lantai 03 


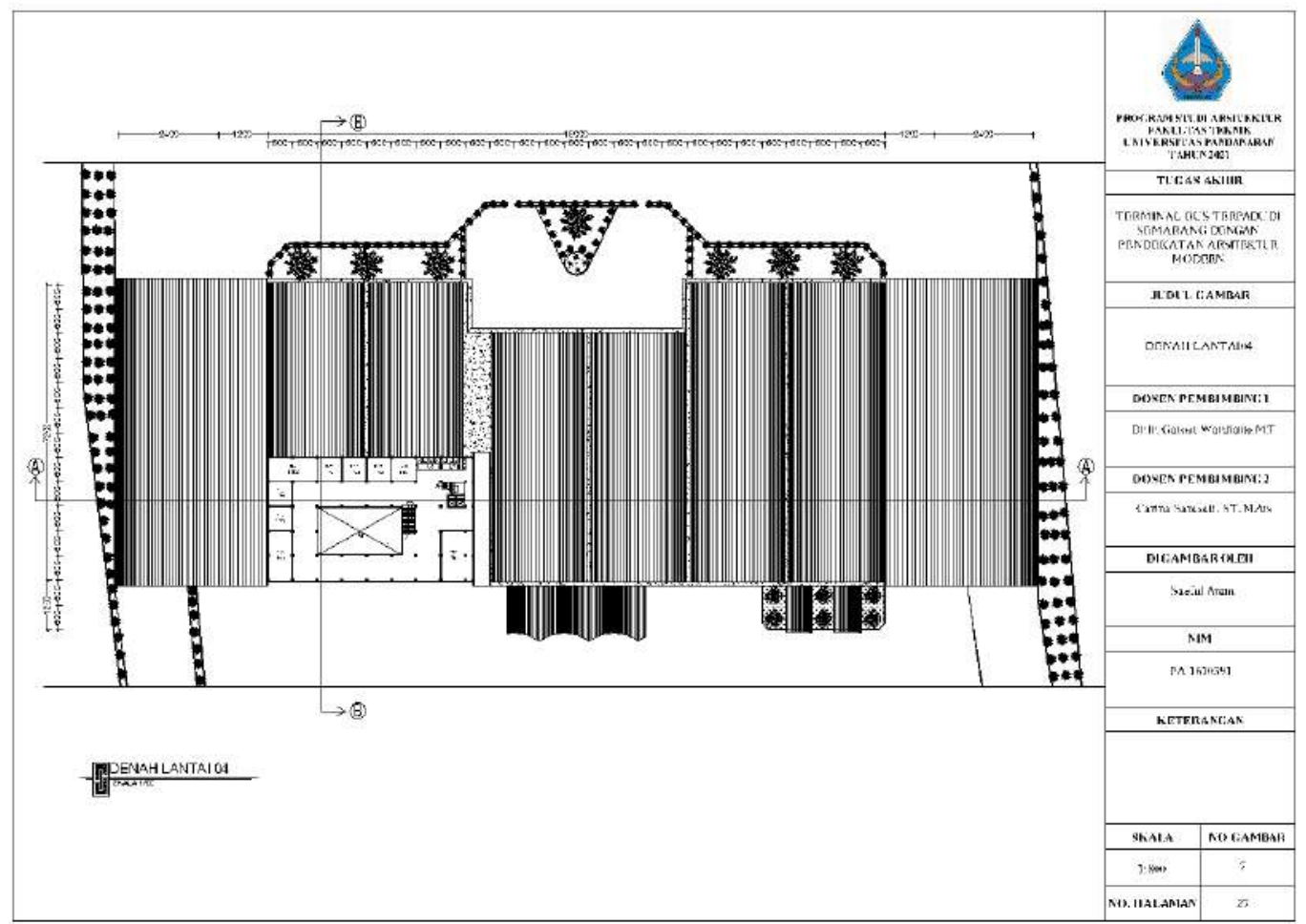

Gambar 21. Denah Lantai 04

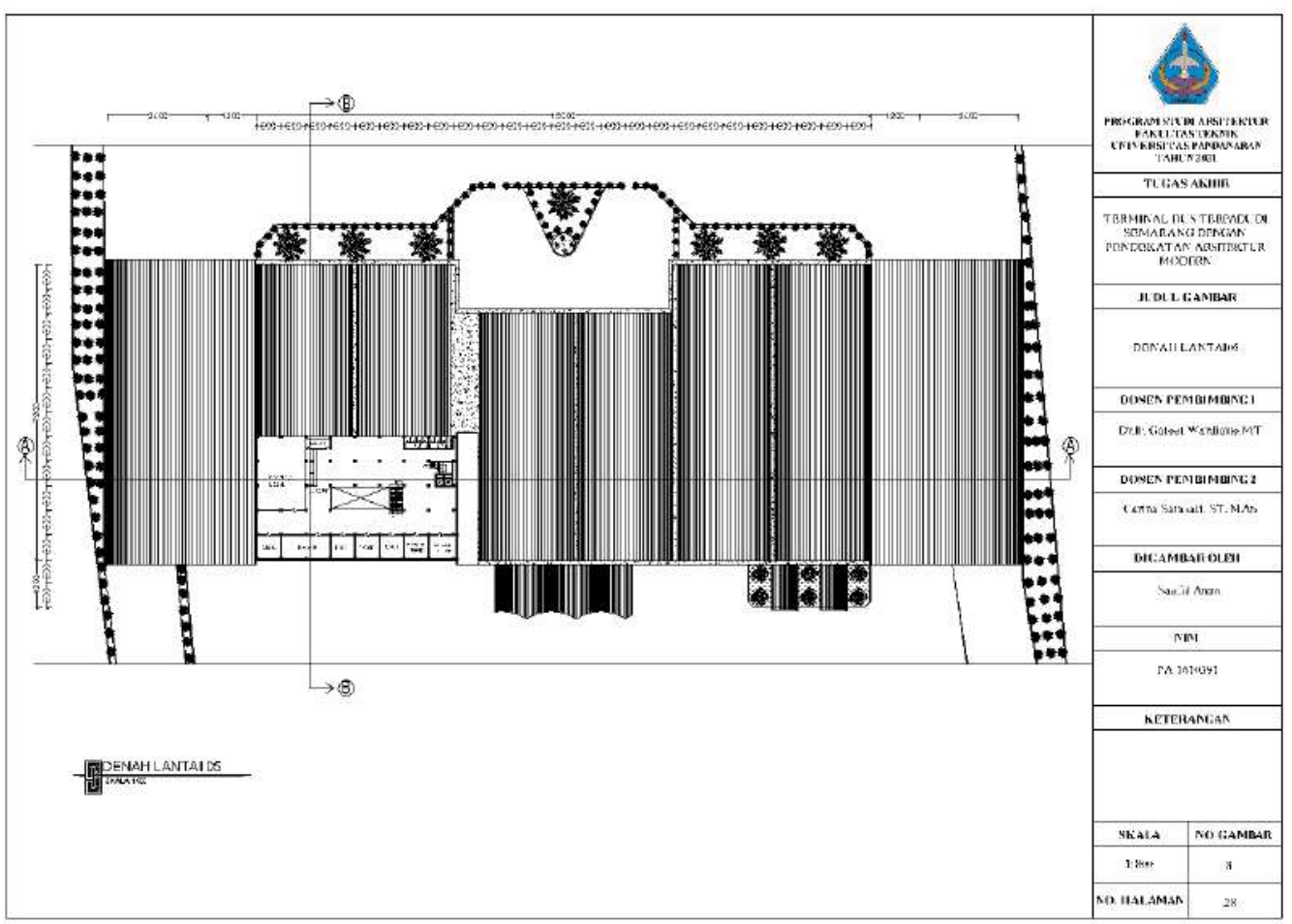

Gambar 22. Denah Lantai 05 


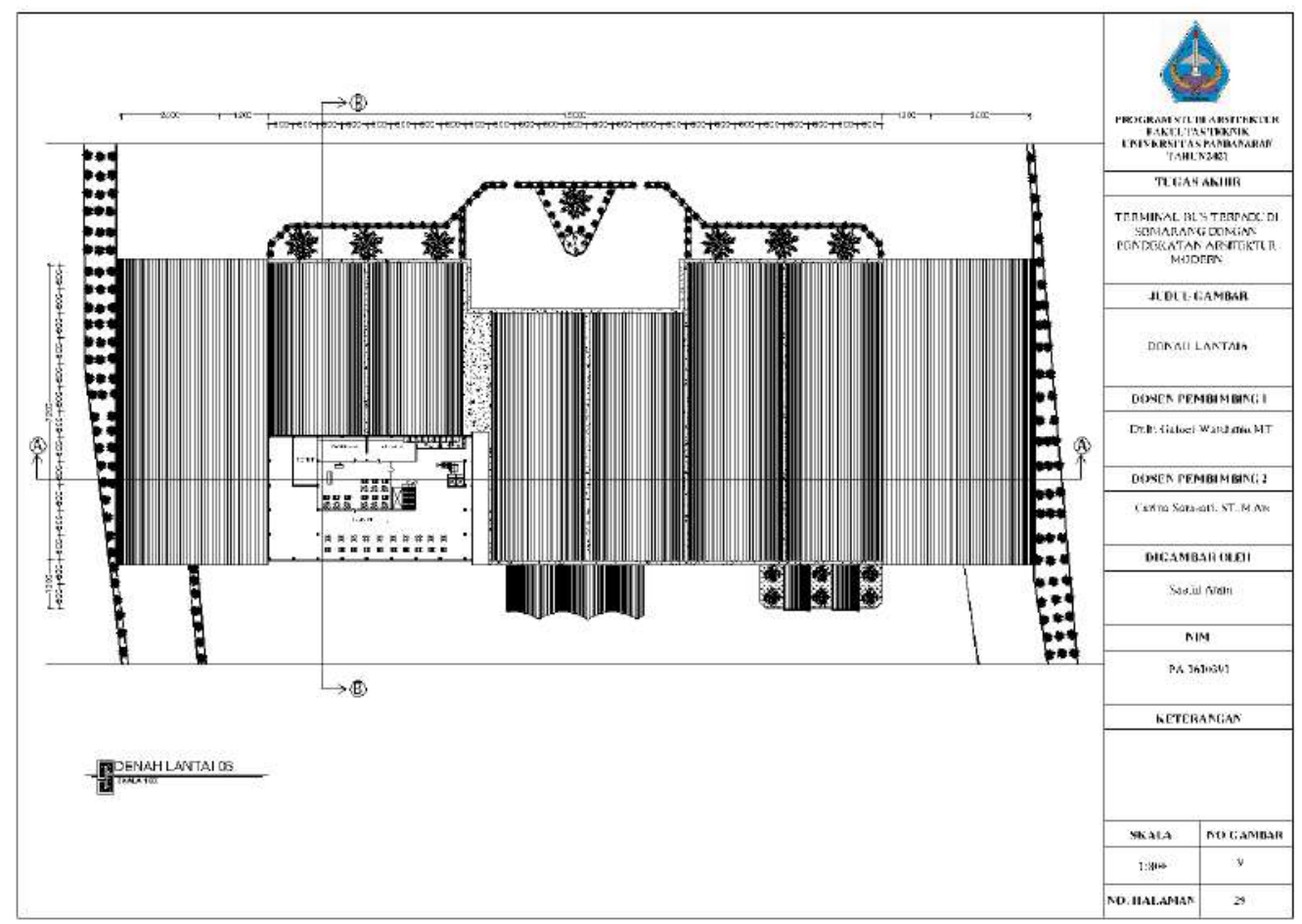

Gambar 23. Denah Lantai 06

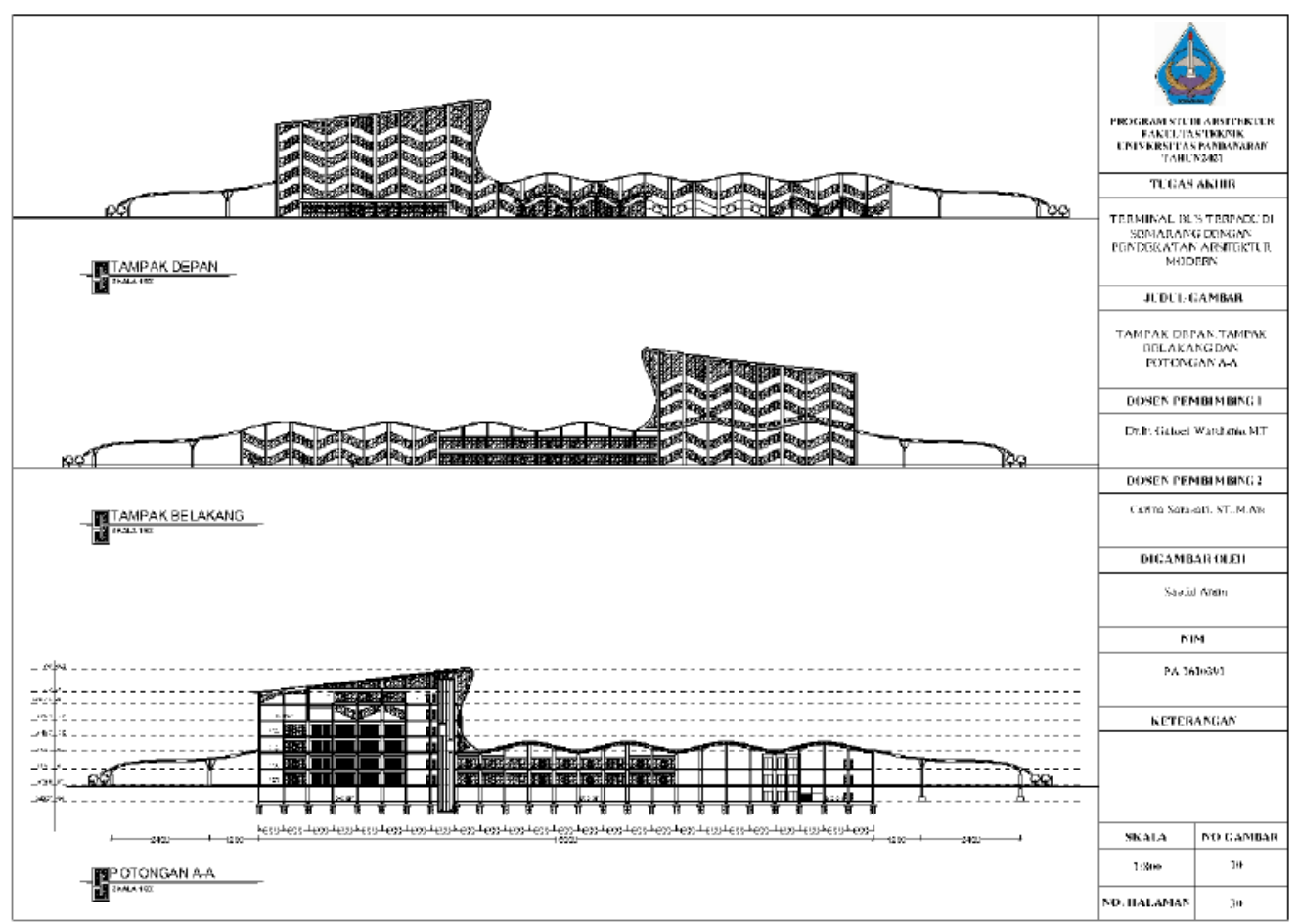

Gambar 24. Tampak Depan, Tampak Belakang dan Potongan A-A 


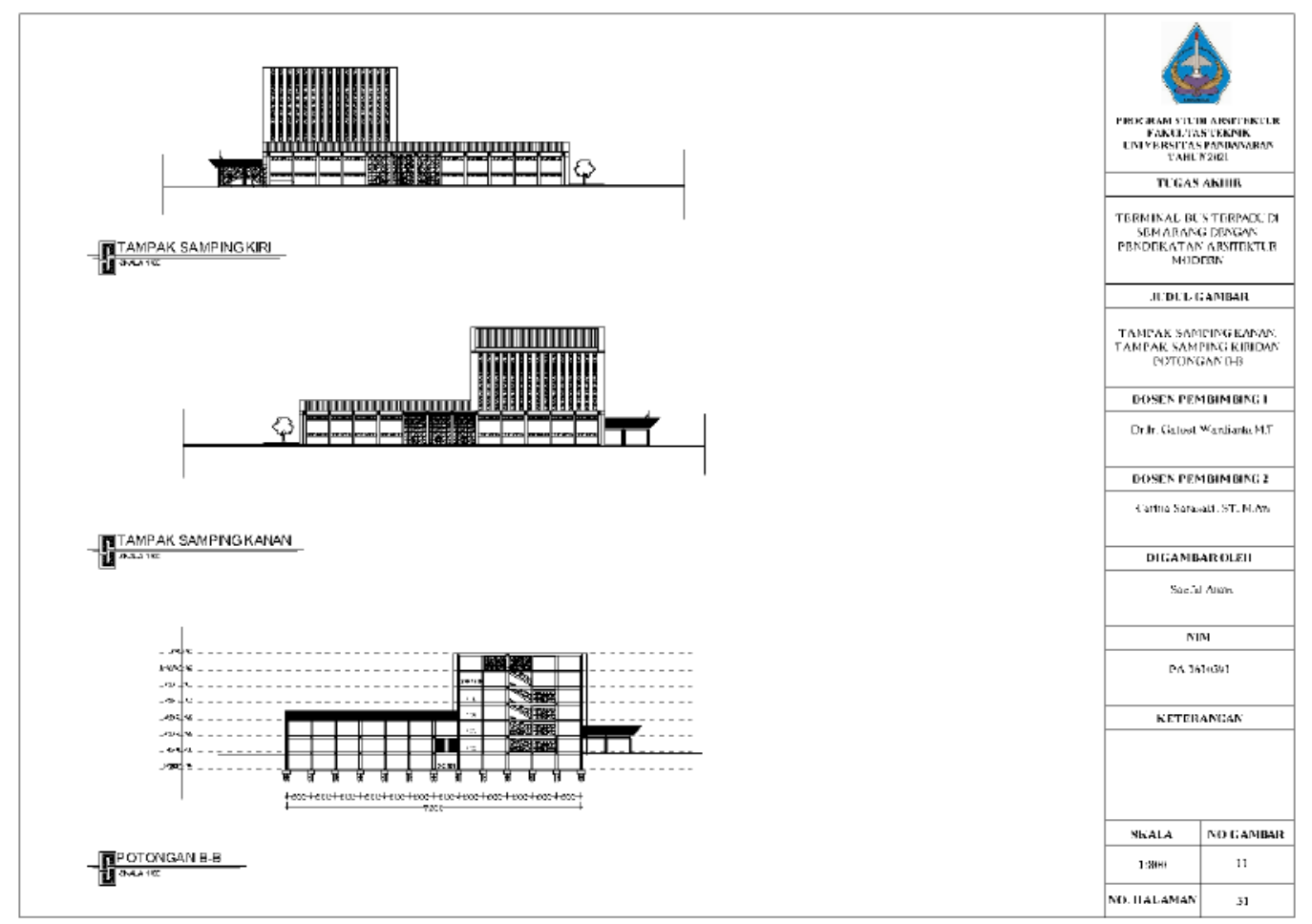

Gambar 25. Tampak Kanan, Tampak Kiri dan Potongan B-B

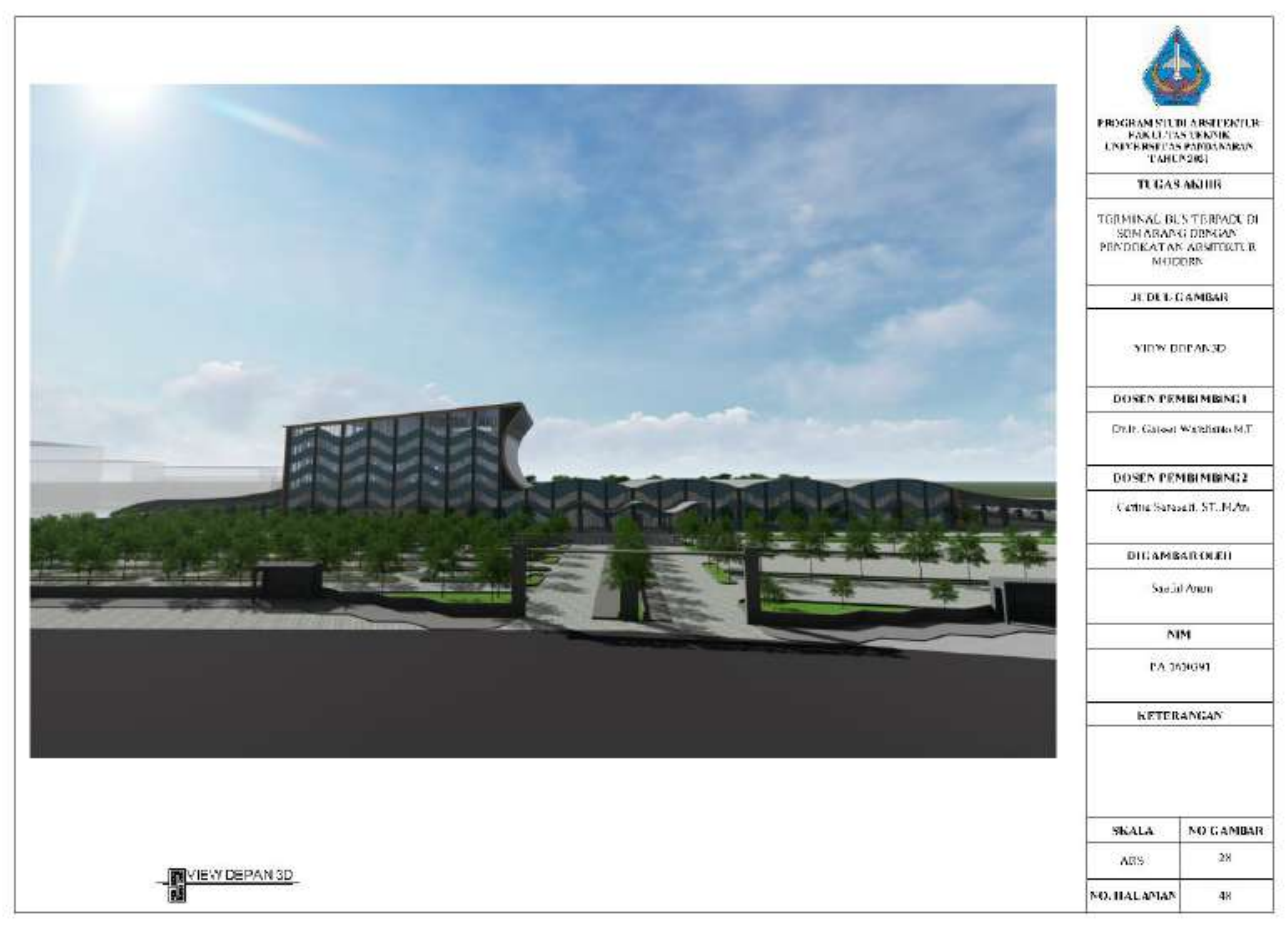

Gambar 26. View Depan 3D 


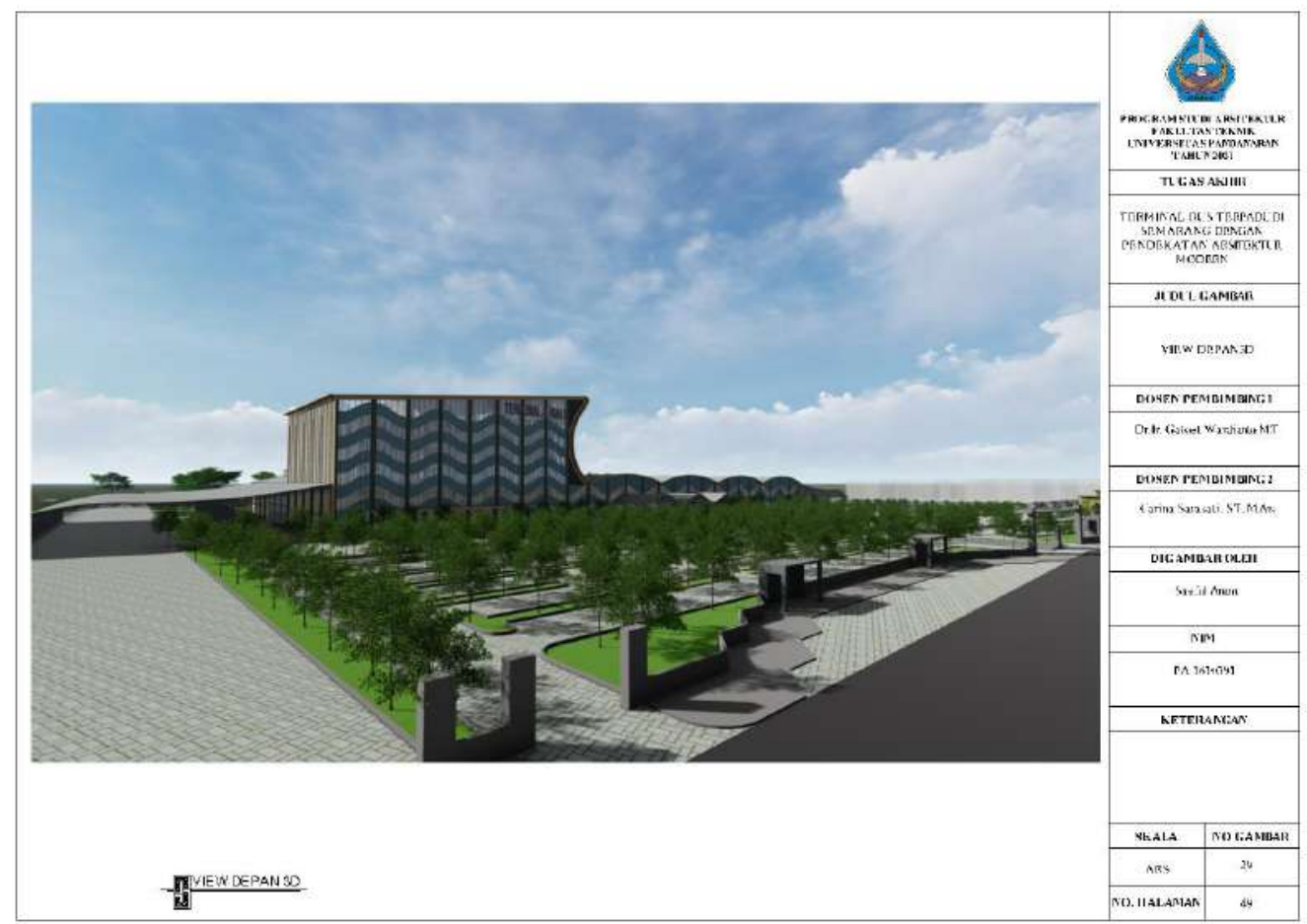

Gambar 27. View Depan 3D

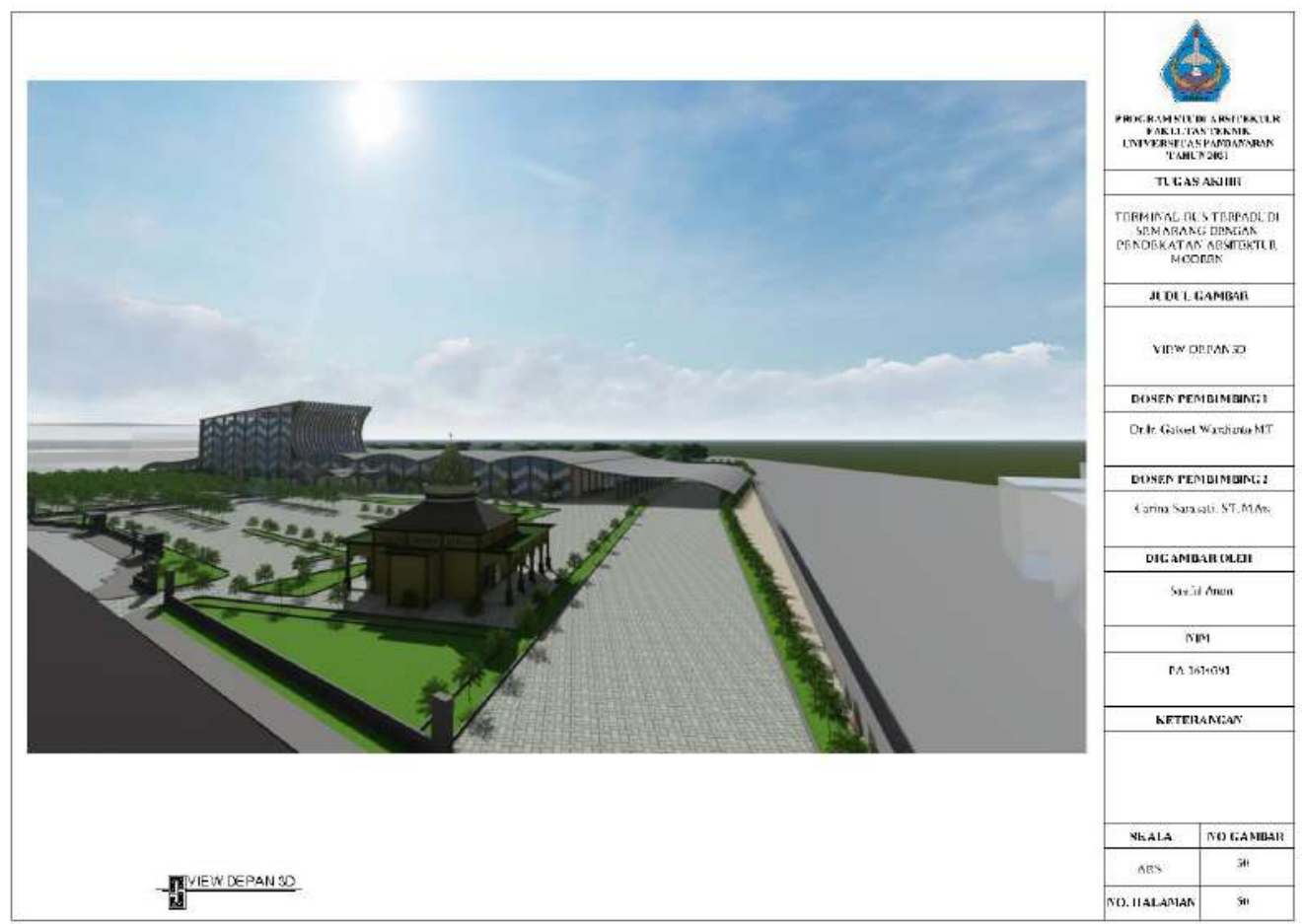

Gambar 28. View Depan 3D 


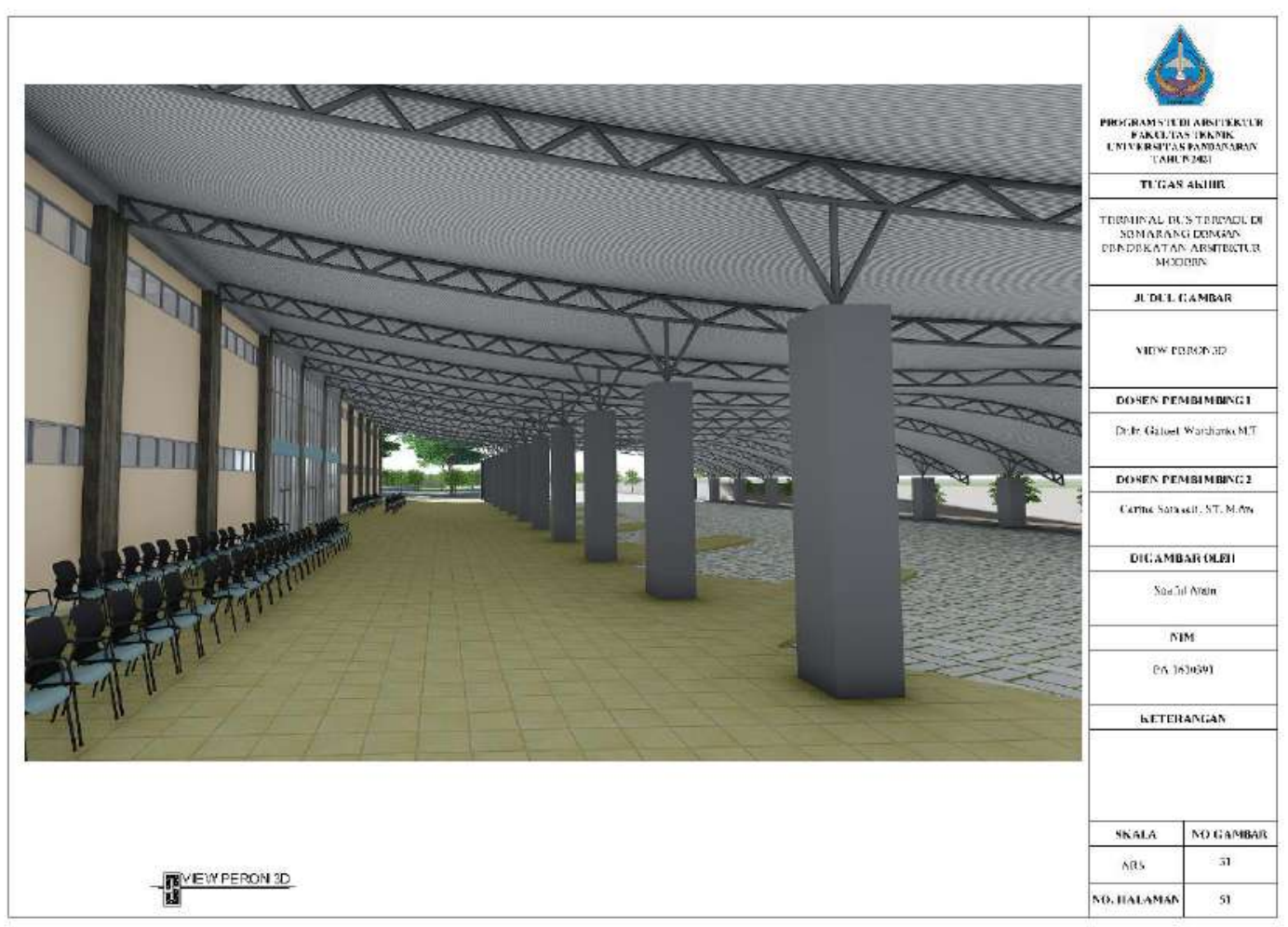

Gambar 29. View Peron 3D

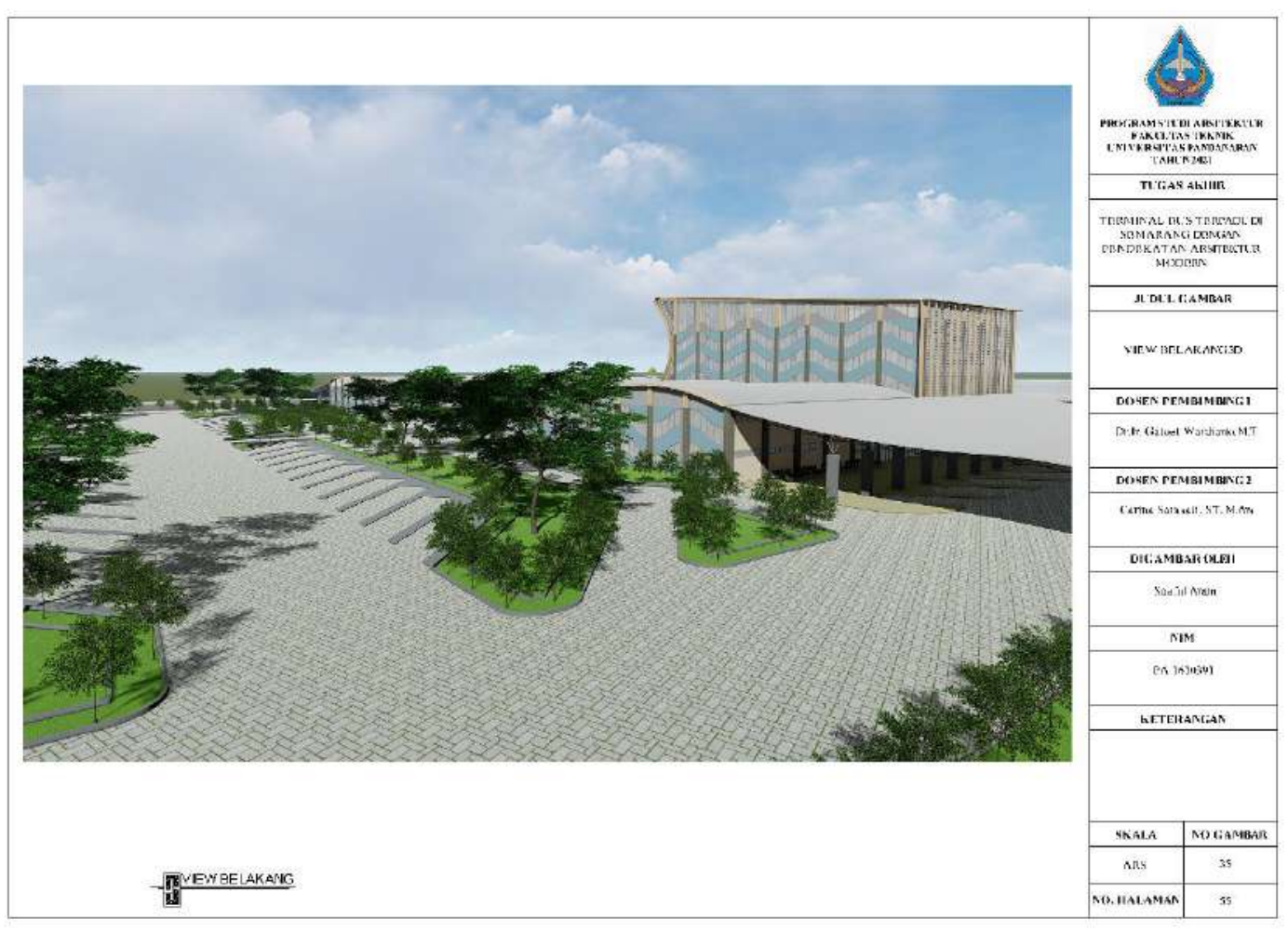

Gambar 30. View Belakang 3D 


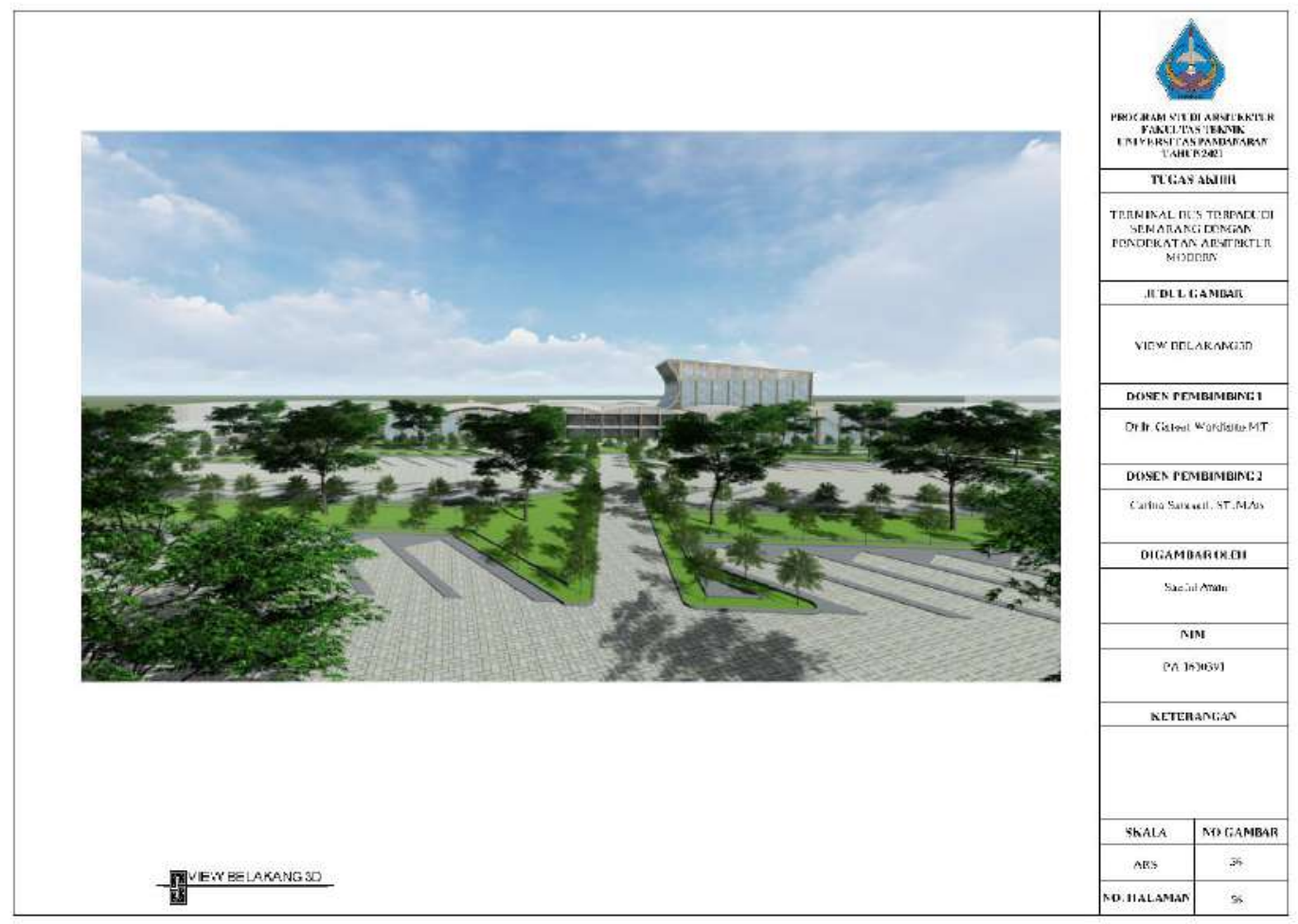

Gambar 31. View Belakang 3D

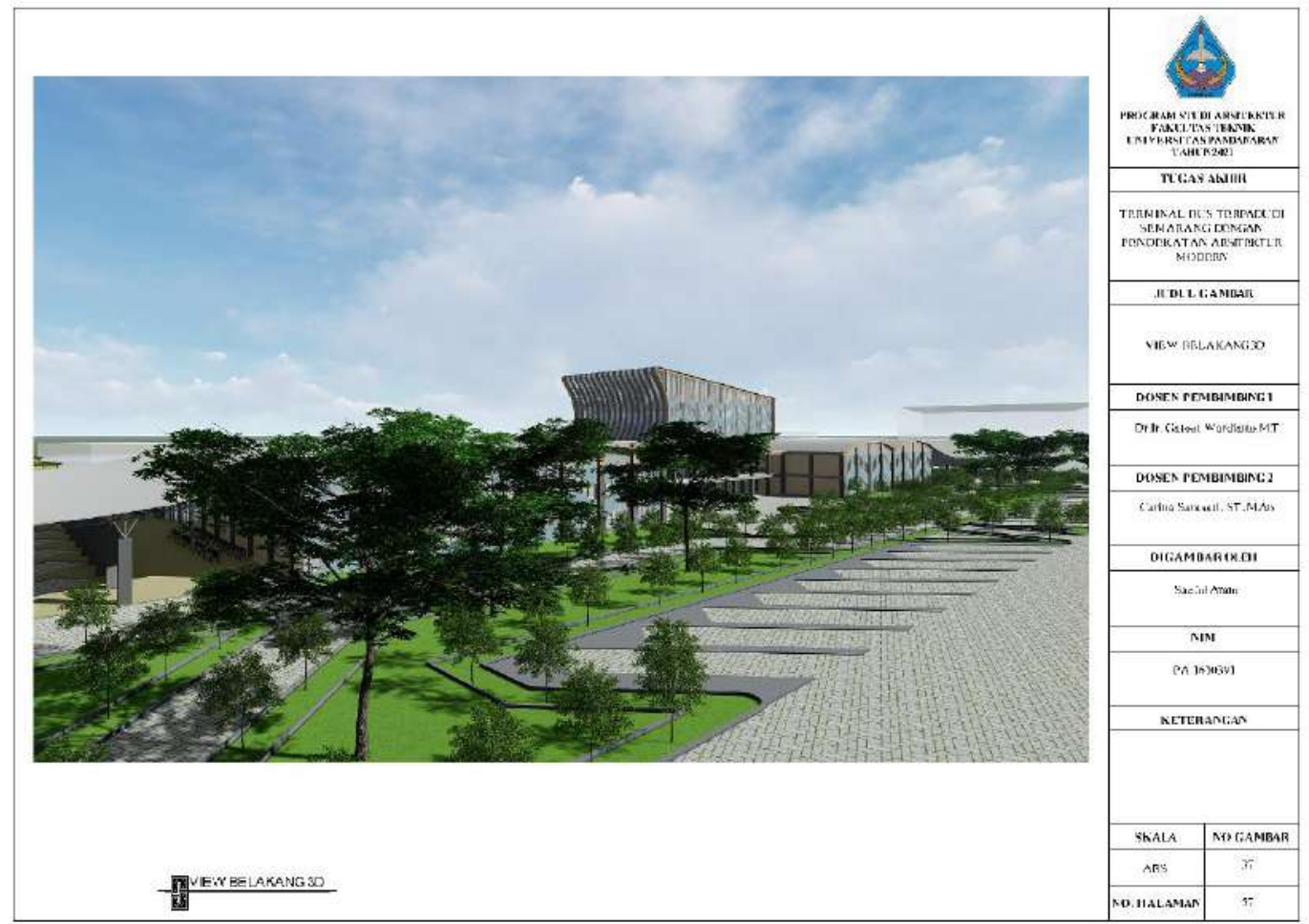

Gambar 32. View Belakang 3D 


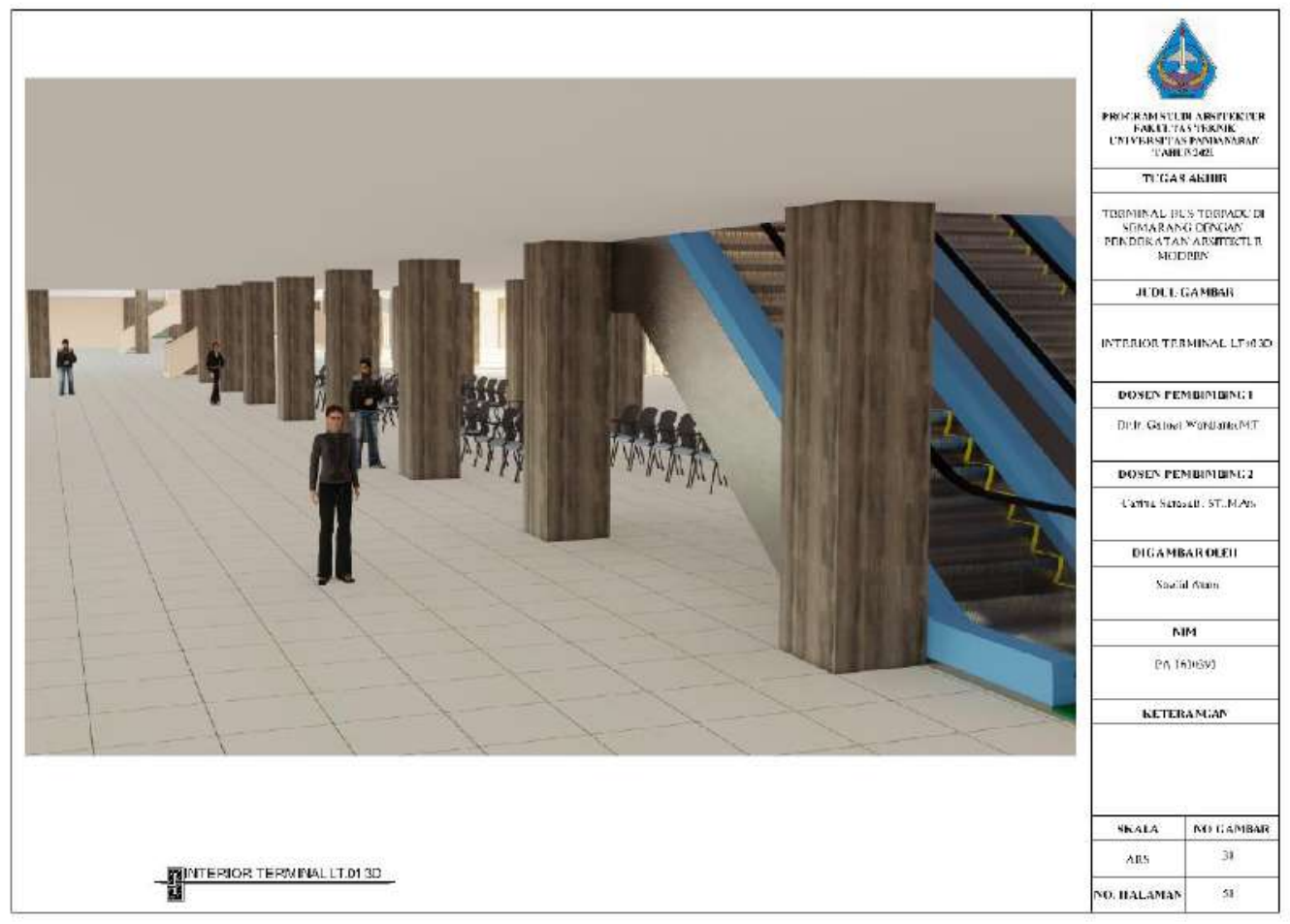

Gambar 33. Interior Terminal Lt.01 3D

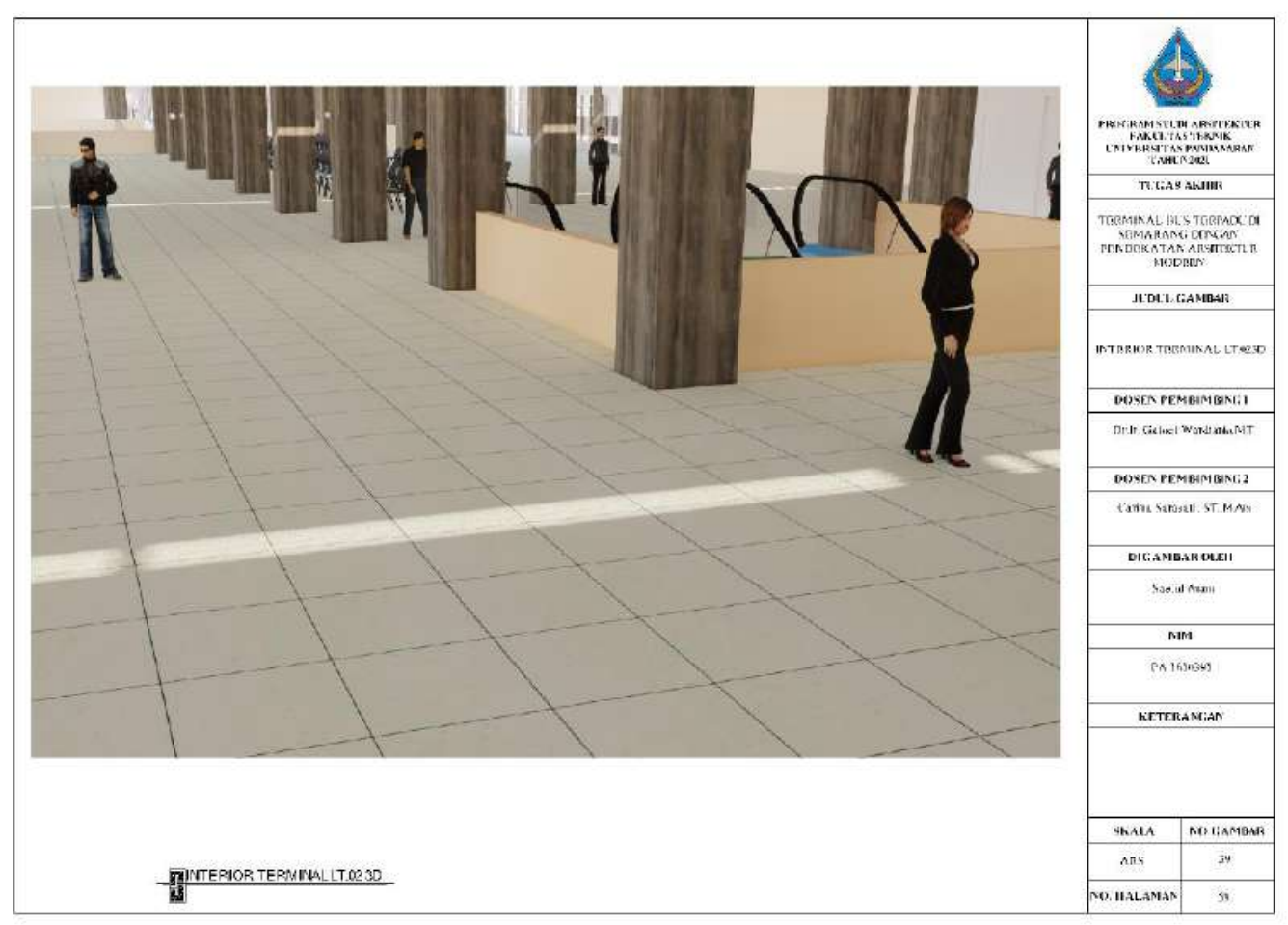

Gambar 34. Interior Terminal Lt.02 3D 


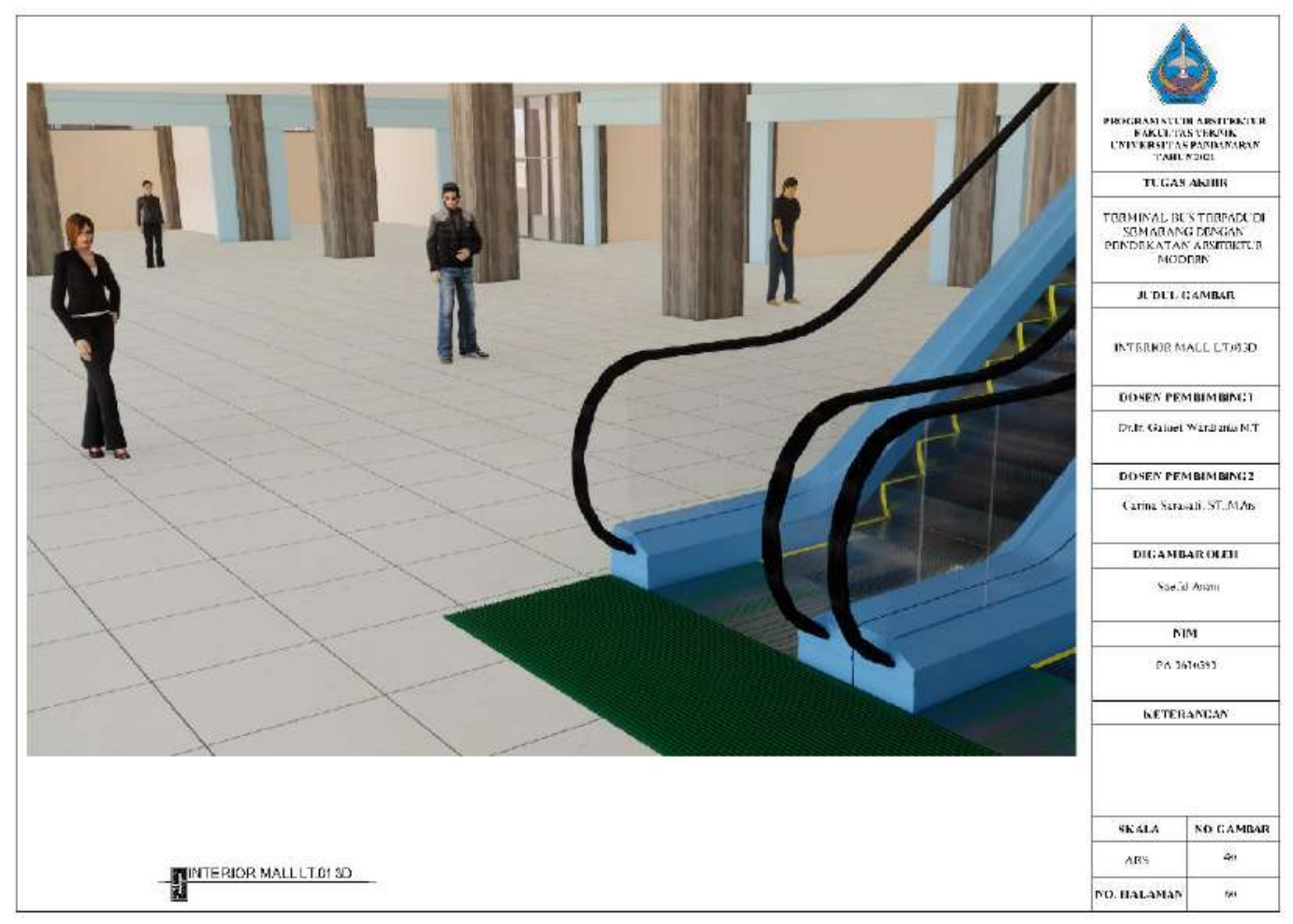

Gambar 35. Interior Mall Lt.01 3D

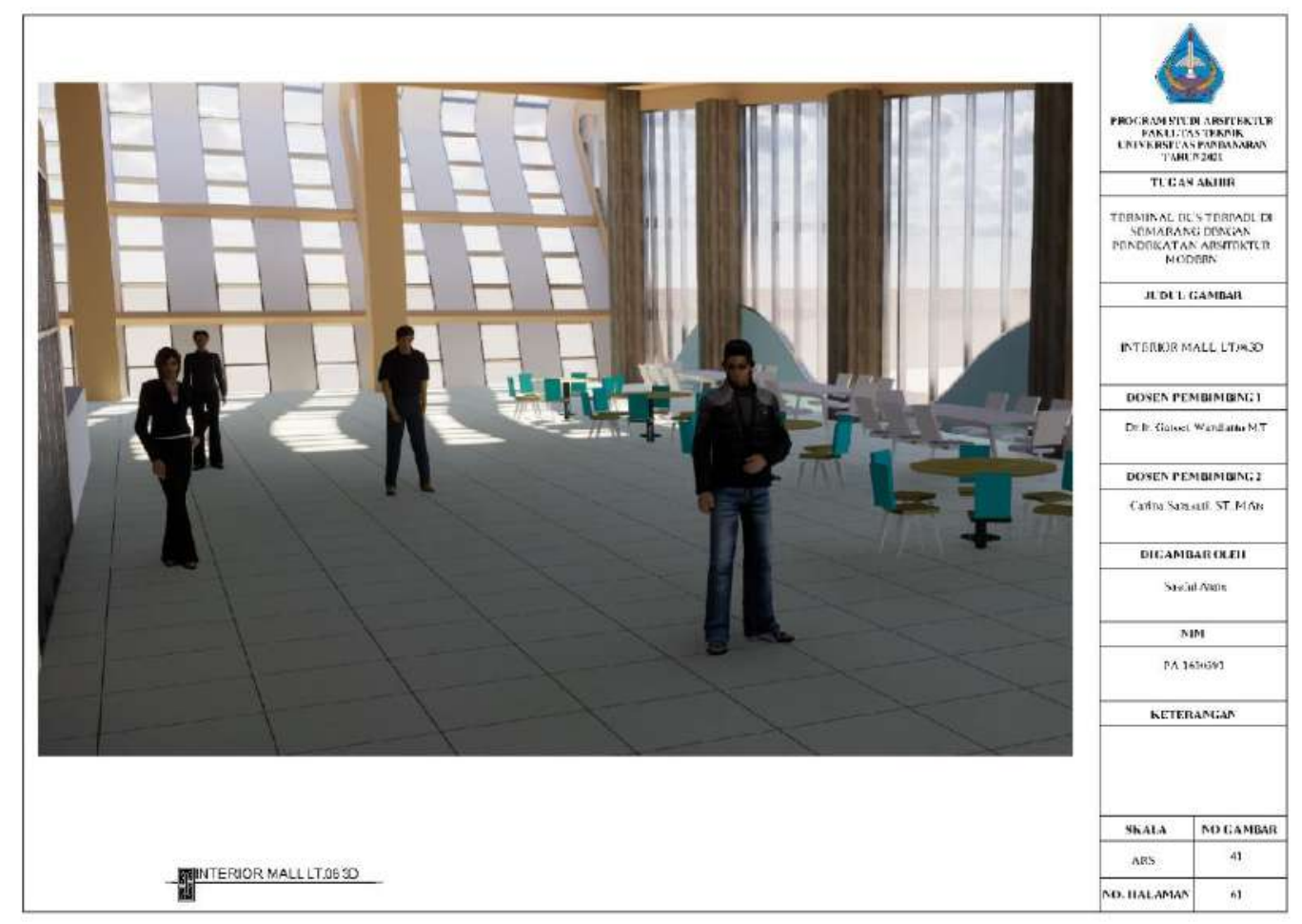

Gambar 35. Interior Mall Lt.06 3D 


\section{KESIMPULAN}

Dalam perencanaan dan perancangan Terminal Bus Terpadu di Kota Semarang dengan pendekatan Arsitektur Modern yang mengekspos dari segi sirkulasi yang efisien dan bentuk massa bangunan yang mengadopsi bentuk sebuah ombak yang membuat bangunan terminal terlihat menarik serta penambahan area komersial yaitu mall pada bangunan terminal.

Pada dasarnya terminal bus di kota semarang sudah ada tetapi dalam segi desain arsitektur perlu adanya penambahan di beberapa titik salah satunya di daerah banyumanik segingga dapat mengatasi masalah transportasi pada masyarakat kota semarang khususnya di banyumanik serta menjadi daya tarik dan ikon dari segi pariwisata ataupun pusat perbelanjaan pada terminal.

\section{DAFTAR PUSTAKA}

Wisnu Sardjono Soenarso, 2016, Pengembangan Science dan Technology Park di Indonesia. Hlm.3. Karyono,T.H. (2001). Teori dan Acuan Kenyamanan Termis dalam Arsitektur,Penerbit Catur Libra Optima,Percetakan Olta Printings, Maret 2001,Jakarta.

Karyono,T.H. (2013). Arsitektur dan Kota Tropis Dunia Ketiga: Suatu Bahasan tentang Indonesia,PT Raja Grafindo,Jakarta,Indonesia.

Ching, Francis D.K. Arsitektur Bentuk, Ruang, dan Tananan. Jakarta. Penerbit Erlangga.

https://www.bappenas.go.id/.

Dinas Tata Ruang Tata Bangunan Pemerintahan Kota Medan (2017). Pengertian dan Konsep Arsitektur Tropis. trtb.pemkomedan.go.id.

Noor Cholis Idham dalam buku (2016) “ Arsitektur Tropis dan Kenyamanan Thermal".
Lippsmeier, G. (2006). Bangunan Tropis. Yogyakarta: Erlangga.

Idealistina,F.(1991). Model Termoregulasi

Tubuh untuk Penentuan Besaran Kesan

Termal Terbaik dalam Kaitanya dengan Kinerja Manusia,Disertasi

Doktor,Institut Teknologi Bandung. 